司会のことば

「農村における脳卒中の近接予知ならびに事前予防について」

$\begin{array}{lll}\text { 林 雅人 } & \text { 秋田 平鹿総合病院副院長 } \\ & \text { 日本女子衛生短期大学教授 } \\ \text { 関 博人 } & \text { 銀座内科センター診療所所長 }\end{array}$

近年食生活の变化（改善？）に上り脳卒中の発生率は減少傾向にあるあのの, 農村部 に打ける脳血管障害は最も重要な疾病の一つであることに変わりはない。一方農村の高 令化現象に加えて脳卒中の発症は寝たきり老人やボケ老人の增加に大きくかかわってい る点も見逃せない。このような背景を考えると脳卒中発症の事前予知と予防対策はきわ めて重要である。

すでに, 脳卒中の危険因子については, 高血圧症をはじめ諸種の因子が詳細に研究さ れてきた。しかし脳卒中発症の近接予知についてはまだ十分明らかにされていないのが 現状である。乙のような関点から本題をシンポジゥムに野田喜代一会長がとりあげられ たあのである。非常に難しいテーマではあるが, 何とか一歩であその本質にせまりたい と念じている。

\title{
I＼cjkstart農村に打ける脳血管疾患死亡の実態
}

まず真島先生に脳卒中の背景因子として農協共済加入者約 1,700 万人の脳血管疾患死 亡統計のまとめを述べていただくが脳卒中死亡者については契約時における身体状況に ついてもふれていただく。膨大な資料よりの統計なのでその成績が注目される。 次いで伊藤先生より長年の剖検成績より脳卒中の内容の変化とその要因について報告が ある。豊富な剖検数からの検討で貴重なデーターがみせていただけるものと思う。

\section{II 脳血管疾患のリスク要因について}

リスク要因については農漁村として静岡県賀茂村の成績を野尻先生に, 山間農村とし て長野県八千穂村を中心に, 年間 8 万人を越す長野県健康管理センターの成績む加えて 磯村先生に, 都市周辺農村として広島市周辺部の成績を関口先生に解析されたデーター を報告していただく。いずれもその地域において長年検診を積み上げられた成績のまと めとその中から脳卒中が発症した例のリスク要因についてのあのでその特長が抽出され るものと期待している。 


\section{III 脳卒中の遠隔予知亡近接予知}

近接予知については野田会長からの要望ああり，各シンポジストとあ検討されている 点で討論も時間をかけて行ないたいと考えているが，進藤先生は Ht 值の上昇とその 変動の仕方が，脳硬塞の発症要因として近接予知になる可能性を検討されている。この 他 Ht 值 $52 \%$ 以上の絶対的多血疾患者の長期的予後, 予防効果についてもふれられる 予定である。

\section{IV 虚血性脳血管障害の近接予知}

心房細動が脳硬塞のリスク要因になっていることは多くの報告があるが，心房細動患 者をHolter心電図を用いて心房細動の出現様式からリスク要因として検討した報告は ない。この点を中心に不整脈の諸問題を細谷先生に報告していただく。また心疾患がリ スクとなって脳硬塞を扟てすととすよく知られているが，発症様式や各心疾患毎の特長 は不明な事柄が多い。乙の点てついて藤原先生に報告していただく。更に藤原先生には

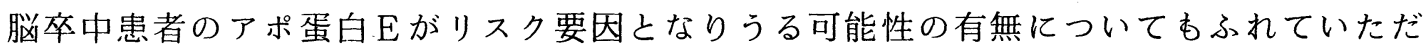
く予定である。

最後に特別発言の形で司会者の一人だが関先生が野田先生と従来から主張されてきた 心力学と脳卒中の関係を心機図という手法で検討して報告する。

おわりに

脳卒中の近接予知はまだまだ難しい問題が山積状態にあるが，その糸口を疫学面，循 環動態, 血液粘性などから攻めてみたい。会場からも多数の発言を期待している。 
農協共済加入者の脳血管疾患死亡統計

$$
\text { 真島三郎（全共連） }
$$

農協共済は主として農村地区を対象として生命、資産等についての保障 を行っている。その主力である生命共済は昭和 59 年度で保有約 1,700 万件に達しているので、これに関して昭和 59 年度の死亡統計ならびに、 一部過去約 10 年間の推移について観察した。

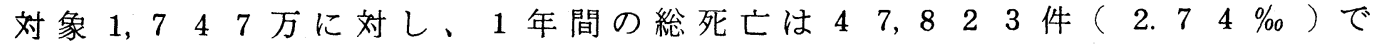
あり、この数字は国民の粗死亡率の $44 \%$ に当る。この中脳血管疾患によ る死亡は 6,236 件（０.36\%）であり、国民統計における值 $1.23 \%$

(昭和 58 年) に比し、かなり低い。死因占率では 1 位悪性新生物（35\%)、 2 位心臓疾患（１６％）、3 位脳血管疾患（１３％）となる。昭和 50 年 からの経過をみると脳血管疾患は死因中第 2 位を占めていたが、年々低下 して昭和 57 年以来心疾患に次いで第3 位となった。

共済加入者の場合、性および年令構成が国民全体とは異り、男性に多く (男女比約 1.9 ：1）、また 15 才以下が少く、7 0 才以上の高令者も少 い。そこで粗死亡率を国民の年令構成に合わせて訂正すると、脳卒中死亡 率は0.57\%となった。この值はなお国民の死亡率の半分以下である。こ の低死亡率の理由は、共済が或程度の健康状態を基礎として加入するのを 原則としていることによると考 えられるが、母数はかなり大き く、年令層も 10 才台以下を除 く各層に分布しているので、年 令階層別扝よび都道府県別の死 亡率をそれぞれ図1、図2 に示 す。

図1にみるように脳卒中死亡率 は年令と共に一様に急増する。 男女差は若年層に大きく、 40 才台では男子が女子の 2 倍以上 であるが、 70 才以上では男女 差が少くなる。都道府県では 1 位秋田、2 位青森、3 位鹿児島、 以下山形、宮城、杤木の順で、 東北地方に高率の県が多い。な 打国民統計上の高率県は高知、

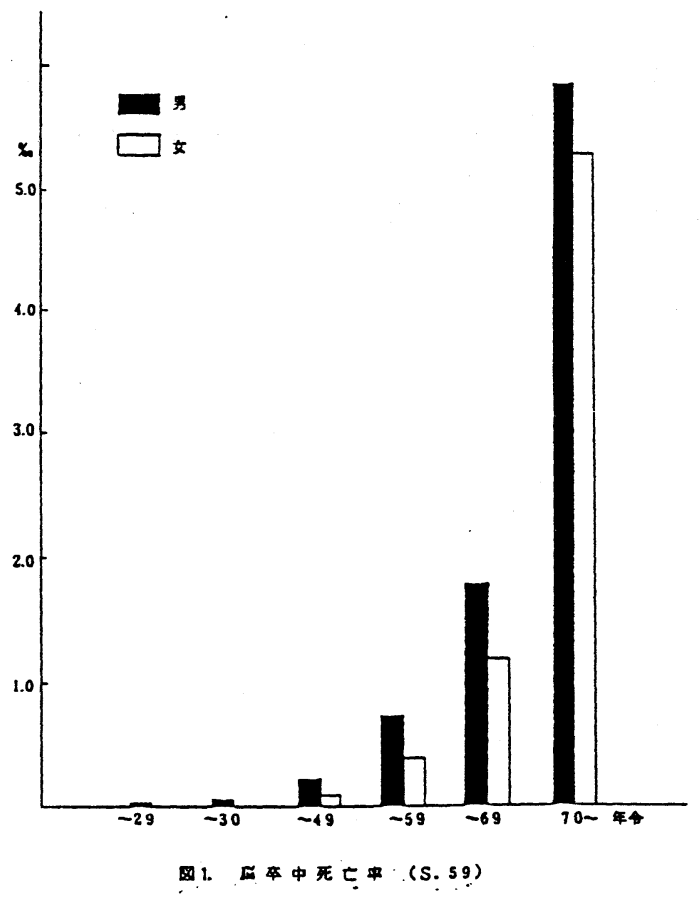


島根、山形、秋田などであり、

若干分布の差がみられる。東北 地方に高率県の多いのは同様で あるが、またいわゆる過疎地域 にも多く、人口の年令構成など の要因も関与しているものであ 万丂。

上述のように共済に加入する さいには体格や既往症、現症の チェックを行う。更に医師によ る理学所見、血圧、尿などの簡 単な検査を行う場合（有詮査） と、医師による馀査は行わない 場合（無診査）とがあり、これ らによって或程度以上に予後不 良と考えられる場合には加入で きない。今回対象例の中 $47 \%$

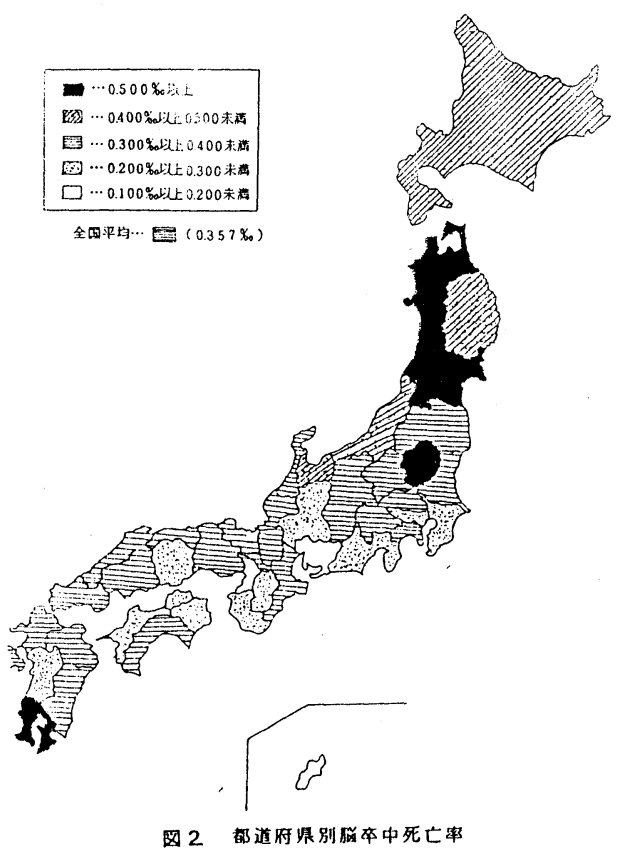
が加入時有診査であり、53\% が無診査であった。両者の脳卒中死亡率を比較すると、全体で有診査例 $0.25 \%$ 、無診査例 $0.44 \%$ であった。国民の人口構成に概算で訂正する と無診查で国民の $70 \%$ 、有診查で国民の 50 \%ぐらいの死亡率に相当する。 このように簡単な病歴チェック、血圧などの検査のみによっても、脳卒中 死亡にかなりの影響があることが分る。

なお他のシンポジストの研究と関連し、脳卒中の危険因子としての心房 細動その他の心電図所見についての考察を加えたい。心房細動に関しては いくつかの可能性があるが、第 1 に塞栓源となる点があげられる。他の心 疾患のない場合は従来まれとされたが、確実な統計は少い。第 2 に心房細 動、脳卒中が共に加令に伴う変性性疾患の結果とする見方があるが、それ のみでは説明困難な事実もある。第 3 に血行動態を介する間接的関与につ いて考察する。心房機能の心出力への影響は諸家による観察があるが、房 室ブロック例にペーシングを行った時の血圧变動などとしてみることもで きる。一方心拍不整の影響として血管平滑筋の収縮を生ずる可能性を示唆 する報告がある。他の心電図所見として ST・T異常もしばしばみられる。 これは要因が多く、一般論は困難であるが、特殊な場合には脳虚血発作と 関連するものがある。 


\title{
農村における脳卒中の近接予知ならびに事前予防について
}

剖検よりみた脳卒中の年次推移

\author{
○伊藤 政志進藤多妃子（内科）佐藤 伸逸（循内） \\ 進藤健次郎（脳外） 小西 正光（大阪成人病センター） \\ 秋田県厚生連由利組合総合病院
}

[はじめに〕：20年間の我々の剖検は1860 例（剖検率 $91 \%$ )であるが、このらち脳卒中は1089例59\%である。今 回はこれらを中心に一部臨床例、検診例を加劣、秋田県農村に括ける脳卒中の病型、病巣の年次推移について述べ てみたい。

[内容]：[表 1 ]は 1860 例の剖検内容である。脳卒中が $59 \%$ 、心筋梗塞が $6 \%$ \%する。図 1 ]〔表 2 ]は病院 のある由利本荘地方 (人口 12 万 5 千人) の地図と全国、秋田県と由利本荘の脳卒中訂正死亡の推移をみたものである。 脳卒中日本一だった秋田県も、それよりもさらに多かった由利本荘もともに最近では全国平均に近ついてきている。 〔表 3 〕は脳底部の動脈硬化をアメリカ、九州と比較したものである。由利本荘の脳動脈硬化はアメリカ、九州に 比しょり高度である。〔表4 〕は心筋梗塞例の脳と心の動脈硬化を由利本荘と大阪のとれとを比較したものである。 由利本荘では心筋梗塞の人といえども脳の動脈硬化の強い人が多く大阪とは異る（心も脳も）。[表5][表 6 ] は剖検脳卒中と心筋梗塞の年次推移と、各病型の5ち70才以上の高令者の占める割合をみたものである。次第に脳 卒中に対し心筋梗塞が、脳出血に対し脳梗塞がふえてきている。又どの病型も高令者の増加が明らかである。〔表 7 了は男子の剖検例で昭和 40 年代と 50 年代の脳出血と脳梗塞の推移をみたものである。梗塞が增しているが、これ は60才以上の高令者の梗塞の増加によるものである。〔表 8 〕は小梗塞と大梗塞の推移をみたものであるが、剖検 梗塞の増加は高令者の大梗塞 (皮質枝) の増加によるものである。〔表 9 〕は心房細動の有無、并膜症と大梗塞の 関連をみたものである。大梗塞の増加は心房細動を有する高令者の梗塞によるものである。〔表10]は高令者の梗 塞と高血压、コレステロールとの関係をみたものであるが、梗塞の大小、心房細動の有無に関係なくいづれも既往 高血圧と密接な関係があり、コレステロールとの関連は少い。〔表11 〕は急性期の症例で脳卒中各病型の推移をみ たものである。脳出血の減少と脳梗塞とくに脳塞栓 ( 心房細動を有する脳梗塞 ) の増加がやはり注目される。

〔表12〕は心房細動の有無と主幹動脈閉塞の推移をみたものである。剖検同様近年心房細動例の大梗塞が増加して いる。〔表13][表14]は検診時の心房細動をみたものである。男女とも加令とともに增加するが、女性に比し男 性に著るしく多い。〔表15]は昭和40年代と昭和50年代の心房細動をみたものであるが、近年高血圧管理の普及と ともに、心房細動が減少してきているのは注目される。〔表16〕〔表17〕は剖検脳出血の病巣の推移をみたもので ある。近年小脳、視床出血がふ方、被豰、橋出血が減少しているが、これは高令者の脳出血の特徵であり、脳出血 でも高令者がふえたためである。〔表18 〕は脳出血急性例で病巣の変遷をみたものであるが、やはり近年視床、小 脳出血が増えている。

[まとめ〕：以上主として剖検例の検討から、近年脳出血が減り、脳梗塞が比較的増加してきている事を述べたが、 これは高令者の心房細動を伴ら大梗塞によるものである。脂質との関係は少なく、既往高血圧と密接な関係があり これらの予防には高血圧対策が大事である事を強張したい。

昭 $41.9 \sim 61.7$

1. 中枢神経系 $\ldots \ldots \ldots \ldots \ldots \ldots \ldots \ldots \ldots \ldots \ldots \ldots \ldots$ 脳出血 脳梗塞 脳動脈瘤破裂 その他 （腫痬 16 )

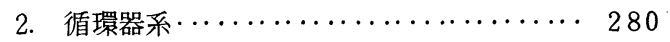
心筋梗塞 大動脈瘤・血栓 (解離性 23 ) 心不全・その他
3. 呼吸器系 $\ldots \ldots \ldots \ldots \ldots \ldots \ldots \ldots \ldots \ldots \ldots \ldots \ldots$

$\left.\begin{array}{ll}\text { 肺癌 } & 36 \\ \text { 肺気腫・肺性心 } & 29 \\ \text { 肺梗塞 } & 10 \\ \text { 肺炎・その他 } & 76\end{array}\right\} 8 \%$

4. 泌尿器系…................... 59 尿毒症 $45 \cdots 2 \%$

5. 血液疾患 $\ldots \ldots \ldots \ldots \ldots \ldots \ldots \ldots \ldots \ldots . . .62$ 白血病等 $58 \cdots 3 \%$

6. その他疾患...$\ldots \ldots \ldots \ldots \ldots \ldots \ldots \ldots \ldots \ldots$ 
図 1 秋田県由利本荘地方

12 万 5 千人

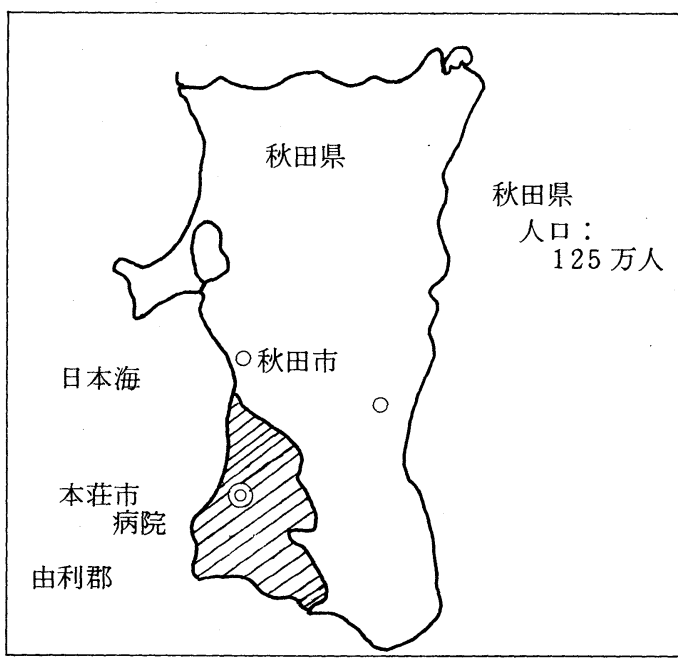

〔表 2]脳血管疾患訂正死亡率の年次推移
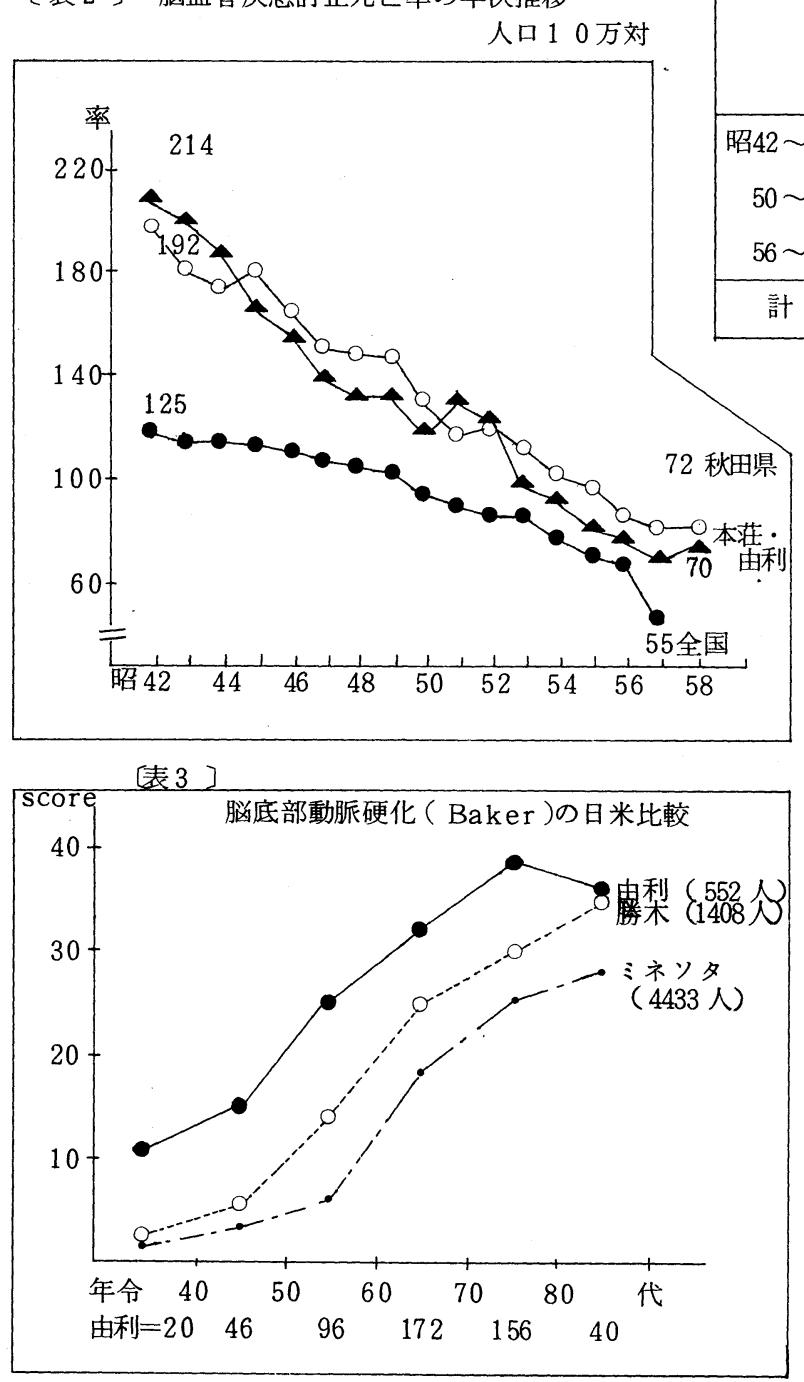

〔表 4 ]脳・心の動脈硬化の比較（男）

( 心筋梗塞例の検討 )

\begin{tabular}{|c|c|c|c|}
\hline \multicolumn{4}{|l|}{ 秋田 } \\
\hline 冠 & 無 & 有 & 計 \\
\hline 無 & 4 & 5 & 9 \\
\hline 有 & 4 & 26 & 30 \\
\hline 計 & 8 & 31 & 39 \\
\hline \multicolumn{4}{|l|}{ 大阪 } \\
\hline 冠 & 無 & 有 & 計 \\
\hline 無 & 3 & 0 & 3 \\
\hline 有 & 7 & 2 & 9 \\
\hline 計 & 10 & 2 & 12 \\
\hline
\end{tabular}

〔表 5 ] 剖検脳卒中と心筋梗塞の年次推移

\begin{tabular}{|c|c|c|c|c|c|}
\hline & 脳梗塞 & 脳出血 & $\begin{array}{l}\text { 心 筇 } \\
\text { 梗 塞 }\end{array}$ & $\begin{array}{l}\text { 脳梗塞+ } \\
\text { 出血 } \\
\text { 心笳梗塞 }\end{array}$ & $\frac{\text { 脳梗塞 }}{\text { 脳出血 }}$ \\
\hline 昭 $42 \sim 49$ & 145 & 131 & 40 & 6.9 & 1.1 \\
\hline $50 \sim 55$ & 188 & 139 & 58 & 5.6 & 1.4 \\
\hline $56 \sim 60$ & 206 & 112 & 68 & 4.7 & 1.8 \\
\hline 計 & 539 & 382 & 166 & 5.5 & 1.4 \\
\hline
\end{tabular}

[表 6] 脳梗塞 - 脳出血 - 心筋梗塞と高令者 (70才以上)

\begin{tabular}{|c|c|c|c|}
\hline 脳梗塞 & 539 人 & 70 才以上. & $\cdot(60 \%)$ \\
\hline 昭42 45 & 44 人 & 12 人 & $(27 \%)$ \\
\hline $46 \sim 49$ & 101 & 55 & $(54 \%)$ \\
\hline $50 \sim 52$ & 92 & 61 & $(66 \%) \uparrow$ \\
\hline $53 \sim 55$ & 96 & 55 & $(57 \%)$ \\
\hline $56 \sim 58$ & 103 & 72 & $(70 \%)$ \\
\hline $59 \sim 60$ & 103 & 67 & $(65 \%)$ \\
\hline 脳出血 & 382 人 & 70才以上 & $\cdot(29 \%)$ \\
\hline 昭 $\overline{42 \sim 45}$ & 55 人 & 6 人 & $(11 \%)$ \\
\hline $46 \sim 49$ & 76 & 12 & $(22 \%)$ \\
\hline $50 \sim 52$ & 68 & 18 & $(26 \%) \uparrow$ \\
\hline $53 \sim 55$ & 71 & 22 & ( $32 \%)$ \\
\hline $56 \sim 58$ & 68 & 33 & $(49 \%)$ \\
\hline $59 \sim 60$ & 44 & 19 & $(43 \%)$ \\
\hline 心筋梗塞 & 166 人 & 70才以上. & $\cdot(54 \%)$ \\
\hline 昭 $42 \sim 45$ & 9 人 & 3 人 & $(33 \%)$ \\
\hline $46 \sim 49$ & 31 & 11 & $(35 \%)$ \\
\hline $50 \sim 52$ & 29 & 19 & $(66 \%) \uparrow$ \\
\hline $53 \sim 55$ & 29 & 13 & $(45 \%)$ \\
\hline $56 \sim 58$ & 40 & 27 & $(68 \%)$ \\
\hline $59 \sim 60$ & 28 & 17 & $(61 \%)$ \\
\hline
\end{tabular}


[表 7 ]脳卒中病型の推移

（30才以上男子剖検 427 例）

\begin{tabular}{|c|cc|l|l|l|}
\hline 年 令 & 時 & \multicolumn{1}{|c|}{ 期 } & 脳出血 & 脳梗塞 & 梗塞/出血 \\
\hline $\begin{array}{c}30 \text { 才 } \\
59 \text { オ }\end{array}$ & 前期 & 昭 $41 \sim 49$ & 37 例 & 14 例 & 0.38 \\
\cline { 2 - 6 } & 後期 & $50 \sim 59$ & 49 & 25 & 0.51 \\
\hline $\begin{array}{c}60 \text { 才 } \\
\text { 以 } \\
\text { 上 }\end{array}$ & 前期 & $41 \sim 49$ & 46 & 54 & 1.17 \\
\cline { 2 - 6 } & 後期 & $50 \sim 59$ & 84 & 178 & 2.12 \\
\hline
\end{tabular}

〔表 8 脳梗塞病型の推移

（30才以上男子剖検 271 例）

\begin{tabular}{|c|c|c|c|c|c|}
\hline 年 令 & 時 & 期 & $\begin{array}{l}\text { 小梗塞 } \\
\text { (穿通枝 })\end{array}$ & $\mid \begin{array}{c}\text { 大梗塞 } \\
\text { (質枝) }\end{array}$ & 合 計 \\
\hline \multirow{2}{*}{$\begin{array}{c}30 \text { オ } \\
\text { 今 } \\
59 \text { オ }\end{array}$} & 前期 & 昭 $41 \sim 49$ & $\stackrel{2}{(14 \%)}$ & $\begin{array}{c}12 \\
(86 \%)\end{array}$ & $\begin{array}{c}14 \\
(100 \%)\end{array}$ \\
\hline & 後期 & 昭50 59 & $\begin{array}{c}6 \\
(24 \%)\end{array}$ & $\begin{array}{c}19 \\
(76 \%)\end{array}$ & $\begin{array}{c}25 \\
(100 \%)\end{array}$ \\
\hline \multirow{2}{*}{$\begin{array}{c}60 \text { 才 } \\
\text { 以 } \\
\text { 上 }\end{array}$} & 前期 & 昭 $41 \sim 49$ & $\begin{array}{l}25 \\
(46 \%)\end{array}$ & $\begin{array}{l}29 \\
(54 \%)\end{array}$ & $\begin{array}{c}54 \\
(100 \%)\end{array}$ \\
\hline & 後期 & 昭 $50 \sim 59$ & $\begin{array}{c}47 \\
(26 \%)\end{array}$ & $\begin{array}{l}131 \\
(74 \%)\end{array}$ & $\begin{array}{l}178 \\
(100 \%)\end{array}$ \\
\hline
\end{tabular}

[表 9 ]大梗塞例の心房細動・心弁膜症合併 （ 30 才以上男子剖検 191 例）
〔表11〕急性期脳塞栓の変遷と予後

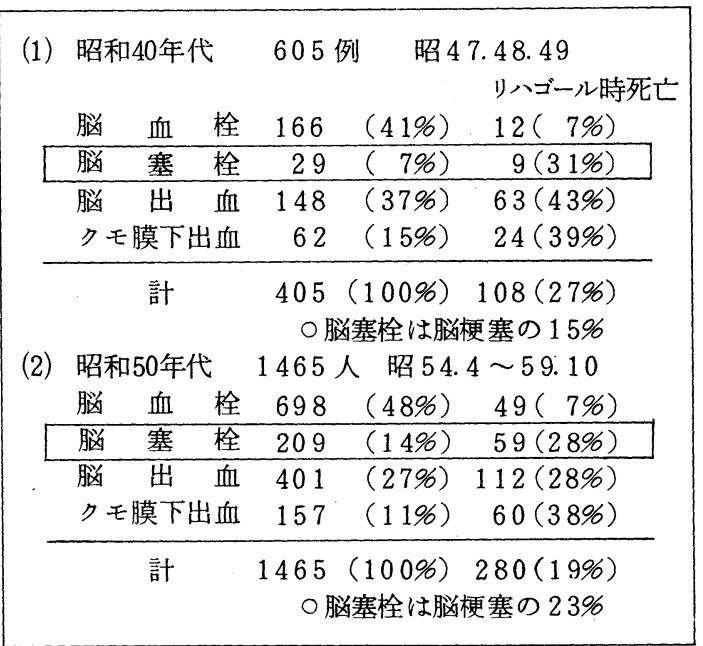

[表12]脳梗塞の心房細動の有無と主幹動脈閉塞 （急性期）

\begin{tabular}{|c|c|c|c|c|}
\hline & & & $\begin{array}{l}\text { 主幹動 } \\
\text { 脈閉塞 }\end{array}$ & \\
\hline 昭和 40 年代 & 心房細動(一) & 456 & & $(13 \%)$ \\
\hline 501 人 & 心房細動(+) & 45 & 12 & $(27 \%)$ \\
\hline 昭和 50 年代 & 心房細動(-) & 321 & 39 & $(12 \%)$ \\
\hline 426 例 & 心房細動(十) & 105 & 41 & $(39 \%)$ \\
\hline
\end{tabular}

\begin{tabular}{|c|c|c|c|c|c|}
\hline 年 令 & 時 期 & 心房細動 (+) & 心房細動(-) & 弁膜 症 (十) & 計 \\
\hline \multirow{2}{*}{$\begin{array}{l}30 \text { オ } \\
59 \text { オ }\end{array}$} & 昭40代 & $3(25 \%)$ & $8(67 \%)$ & $1(8 \%)$ & $12(100 \%)$ \\
\hline & 昭50代 & $5(26 \%)$ & $12(63 \%)$ & $2(11 \%)$ & $19(100 \%)$ \\
\hline \multirow{2}{*}{$\begin{array}{c}60 才 \\
\text { 以 } \\
\text { 上 }\end{array}$} & 昭 40 代 & $11(31 \%)$ & $15(52 \%)$ & $3(10 \%)$ & $29(100 \%)$ \\
\hline & 昭50代 & $67(51 \%)$ & $55(37 \%)$ & $10(8 \%)$ & $131(100 \%)$ \\
\hline
\end{tabular}

[表10]高令脳梗塞と高血圧・コレステロール ( 60 才以上男子 231 例)

\begin{tabular}{|c|c|c|c|c|c|}
\hline 病 & 小 & 塞 & 大 & 梗 & 塞 \\
\hline 心房細動 & 心房細動 $(+)$ & 心房細動(-) & 心房細動(+) & 心房細動(-) & 弁 膜 症 \\
\hline 高 血 圧 者 ( & $8 / 1080 \%$ & $50 / 6281 \%$ & $63 / 7782 \%$ & $54 / 6978 \%$ & $8 / 13 \quad 61 \%$ \\
\hline 高コレステロール血者 (め) & $2 / 9(22 \%)$ & $8 / 58(14 \%)$ & $7 / 77(9 \%)$ & $13 / 67(19 \%)$ & $6 / 13 \quad 0$ \\
\hline 血清コレステ & $182( \pm 50)$ & $176( \pm 40)$ & $171( \pm 37)$ & $186( \pm 29)$ & $167( \pm 14)$ \\
\hline
\end{tabular}


[表13]循環器検診と心房細動

\begin{tabular}{|rrr|}
\hline 年次 & 受 診 者 & 心房細動(@) \\
\hline 昭 47 & 4260 & $56(1.3)$ \\
48 & 5364 & $50(0.9)$ \\
49 & 4944 & $56(1.1)$ \\
50 & 4779 & $40(0.8)$ \\
51 & 5490 & $44(0.8)$ \\
\hline 57 & 9796 & $55(0.6)$ \\
58 & 9420 & $72(0.8)$ \\
59 & 11725 & $82(0.8)$ \\
\hline 計 & 55778 & $455(0.8)$ \\
\hline
\end{tabular}

[表 15 ] 検診と心房細動推移

\begin{tabular}{|l|rrrr|}
\hline \multicolumn{1}{|c}{50 代 } & 60 代 & 70 代 & 80 代 \\
\hline 昭和 $47 \sim 51$ & $0.95 \%$ & $4.40 \%$ & $5.96 \%$ & $16.42 \%$ \\
\hline 昭和 $57 \sim 59$ & $1.15 \%$ & $2.18 \%$ & $4.49 \%$ & $4.65 \%$ \\
\hline 女 & & & & \\
\hline 昭和 $47 \sim 51$ & $0.44 \%$ & $1.10 \%$ & $4.74 \%$ & $8.33 \%$ \\
\hline 昭和 $57 \sim 59$ & $0.46 \%$ & $0.60 \%$ & $1.80 \%$ & $4.70 \%$ \\
\hline
\end{tabular}

[表14]検診と心房細動性と年令

\begin{tabular}{|c|c|c|c|c|c|c|c|}
\hline 男 & 20代以下 & 30 & 40 & 50 & 60 & 70 & 80代以上 \\
\hline 受 診者 & 2635 & 4671 & 7805 & 6860 & 3858 & 1211 & 196 \\
\hline 心房細動 & 0 & 2 & 30 & 73 & 126 & 61 & 17 \\
\hline (6) & $(0)$ & $(0.04)$ & $(0.38)$ & $(1.06)$ & $(3.27)$ & $(5.04)$ & $(8.67)$ \\
\hline \multicolumn{8}{|l|}{ 女 } \\
\hline 受診者 & 1906 & 4047 & 7663 & 7135 & 5125 & 1669 & 197 \\
\hline 心房細動 & 0 & 1 & 17 & 32 & 43 & 42 & 11 \\
\hline (2) & $(0)$ & $(0.02)$ & $(0.22)$ & $(0.45)$ & $(0.84)$ & $(2.52)$ & $(5.58)$ \\
\hline
\end{tabular}

[表16]剖検脳出血病巣の推移 351 例

\begin{tabular}{|c|c|c|c|c|c|c|c|}
\hline & 皮質下(め) & 被殼( & 混 合 (b) & 視 床 (b) & 小脳 (め) & 橋 & 70 以上( \\
\hline $\begin{array}{c}\text { 昭 } 41.9 \text { 〜昭 } 49 \\
(121 \text { 人) }\end{array}$ & $4(3)$ & $52(43)$ & $13(11)$ & $25(21)$ & $5(4)$ & $22(18)$ & $17(14)$ \\
\hline $\begin{array}{r}\text { 昭 } \begin{array}{r}0 \\
(230 \text { 昭 } 59\end{array} \\
\end{array}$ & $16(7)$ & $83(36)$ & $14(6)$ & $69(30)$ & $15(7)$ & $33(14)$ & $78(34)$ \\
\hline
\end{tabular}

[表 17 高令者の脳出血病巣

\begin{tabular}{|c|c|c|c|c|c|c|c|}
\hline & 皮質下(的) & 被 款( & 混 合 (b) & 視 床 (め) & 小脳 (め) & 橋 (0) & 計 (2) \\
\hline 70 才以上 & $8(9)$ & $29(31)$ & $7(7)$ & $32(34)$ & $12(13)$ & $6(6)$ & $94(100)$ \\
\hline 69 才以上 & $7(7)$ & $120(49)$ & $6(2)$ & $73(30)$ & $9(4)$ & $21(\stackrel{\downarrow}{9})$ & $246(100)$ \\
\hline
\end{tabular}

〔表 18 C T 導入前の脳出血病巣の推移（1 週間以内入院）＼cjkstart脳出血 802

\begin{tabular}{|c|c|c|c|c|c|c|c|}
\hline $\mathrm{C} T$ 前 & 皮質下(@) & 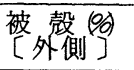 & 混 合 (O) & 視床( & 小脳 ( & 橋 (口) & 偏位なし(め) \\
\hline 昭 $460 \sim 49$ & & $90(47)$ & $29(15)$ & $11(6)$ & $4(2)$ & $18(9)$ & $21(11)$ \\
\hline 昭 $\begin{array}{llll}5 & 0 & \sim & 53 \\
2 & 1 & 2 & \\
0\end{array}$ & $17(8)$ & $116(55)$ & $9(4)$ & $44(21) \Uparrow$ & $11(5) \Uparrow$ & $10(5)$ & $5(2)$ \\
\hline 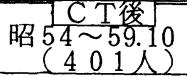 & $34(8)$ & $172(42)$ & $7(2)$ & $125(31)$ & $31(8)$ & $32(8)$ & \\
\hline
\end{tabular}




\section{野尻雅美（千葉大学看護学部基礎保健学講座）}

\section{[研究目的] :}

昭和 $40-60$ 年の 20 年間にわたり、毎年実施されてきた静岡県賀茂村の集団検診 の成績より、後ろ向きにコホートを作成した。このコホートにより脳血管疾患及び心 疾患のリスク要因を検討した。更に昭和 40 年代と 50 年代の $2 つ の$ 観察コホートに 分け、各々のリスク要因を比較し、リスク要因の関与の変動について検討した。

[対象と方法]：

対象 1 は昭和 $39 ， 40 ， 41$ 年に高血圧集団検診を受診した $30 \sim 69$ 歳の賀茂村 住民、男 634 人、女 1025 人で、これらを昭和 60 年まで 20 年間追跡した（4 $0 \sim 60$ 年コホート)。対象 2 は対象 1 と同じ対象で昭和 $39 、 40 、 41$ 年より昭 和 50 年まで 10 年間追跡した ( 40 年コホート)。対象 3 は昭和 $49,50,51$ 年に同じく高血圧集団検診を受診した同年龄の住民、男 404 人、女 880 人で、こ れらを昭和 60 年まで 10 年間追跡した（50 年コホート）。各々の観察コホートの 人数と脱落者の人数の性・年齢階級別構成は表 1 に示した。解析に当たり $30-49$ 歳を中年、 $50 \sim 69$ 歳を高年とした。

これらのコホートの予後調査は、毎年、死亡診断書を用い、死亡と死因を確認した。 死因の分類は国際疾病分類の簡単分類を用いた。また昭和 60 年末には保健婦および 保健推進員の協力を得て、3つのコホート全員の生活実態調查を実施、生死を確認す ると共に、生活実態を把握した。

疫学的分析として各観察コホート別にリスク要因と考えられる各項目の検查值カテ エ゙リ一群別に死亡率を算出、次いで正常値群と各異常値群の死亡率間の相対危険 R・ $\mathrm{R}$ 算出した。死亡率の有意差検 定は $\chi^{2}$ 検定ないしFISCHER の直 接確率法を用いた。有意水準とし $\tau$ *印は $\mathrm{P}<0.01$ 、**印は $\mathrm{P}<0$. 05を示した。なお、中年の死亡率 が低く統計学的解析にたえうる標 本数に達していないために、リス ク要因の検討は高年のみを対象と した。

集計・解析には東京大学大型電 算機センターを使用した。

[研究結果]：

$1:$ 各観察コホートのカバー率及 び追跡率（表 1)

\begin{tabular}{|c|c|c|c|c|c|c|c|c|}
\hline & $\begin{array}{l}\text { 全人* } \\
\text { 口. }\end{array}$ & ユホート & b/a & 調查 & $\begin{array}{l}\text { 末調 } \\
\text { 查数 }\end{array}$ & $\mathrm{c/b}$ & 告 & 死 \\
\hline 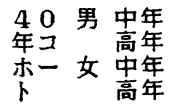 & $\begin{array}{l}754 \\
442 \\
791 \\
494\end{array}$ & $\begin{array}{l}353 \\
281 \\
627 \\
401\end{array}$ & $\begin{array}{l}46.8 \\
63.6 \\
79.3 \\
81.2\end{array}$ & $\begin{array}{l}319 \\
269 \\
571 \\
367\end{array}$ & $\begin{array}{l}34 \\
12 \\
56 \\
34\end{array}$ & $\begin{array}{l}90.4 \\
95.7 \\
91.1 \\
91.5\end{array}$ & $\begin{array}{l}309 \\
195 \\
559 \\
317\end{array}$ & $\begin{array}{l}10 \\
74 \\
12 \\
50\end{array}$ \\
\hline 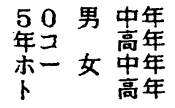 & $\begin{array}{l}802 \\
485 \\
731 \\
590\end{array}$ & $\begin{array}{l}215 \\
189 \\
521 \\
359\end{array}$ & $\begin{array}{l}26.8 \\
39.6 \\
71.3 \\
60.8\end{array}$ & $\begin{array}{l}208 \\
183 \\
490 \\
346\end{array}$ & $\begin{array}{r}7 \\
6 \\
31 \\
13\end{array}$ & $\begin{array}{l}96.7 \\
96.8 \\
94.0 \\
96.4\end{array}$ & $\begin{array}{l}200 \\
160 \\
476 \\
329\end{array}$ & $\begin{array}{r}8 \\
23 \\
14 \\
17\end{array}$ \\
\hline
\end{tabular}

表 20060 年コホート、性・年龄階級別、死因病型別死亡事

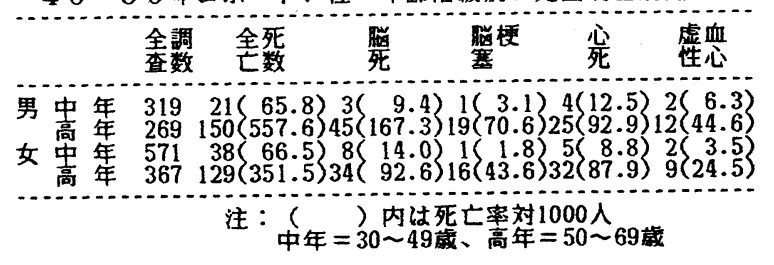




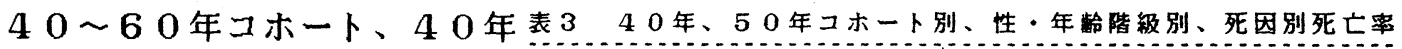
コホート及び 50 年コホートの当 該人口に占める割合、すなわち力 バー率は前二者は全体では67. $0 \%$ 、後者は全体では $49.2 \%$ であった。

次に、これらの観察コホートの 追跡率については、前二者は、全 体では 91 . $8 \%$ 、後者は、全体

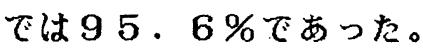

$2 ：$ 各観察コホート別、性別、年 齡階級別、死因別死亡率（表 2 、 3)

$40-60$ 年観察コホートにつ いて、畄血管疾患死（脳死）及び 心疾患死（心死）の死亡率間に性 差はなかった。中年に比し高年で は脳死、心死共に有意に高率であ った。 40 年コホートと 50 年コ ホートとの間には、中年では差が ないが、高年の男の脳死について は有意に後者に低かった。

$3: 40 \sim 60$ 年コホートのリス ク要因（表 4、5）

正常値群との間に死亡率に有意 差のあった項目は、畄死では最大 血圧**（男女）、最小血圧**（女 ）、 $\mathrm{S} \mathrm{H}^{*}$ (男女) 、 $\mathrm{S} \mathrm{S}^{*}$ (男)

、E C G（心房細動**、女）、そ の他（以下、表略）、肥满*（女 ）、従前の喫煙*（男）、従前の 飲酒**（男）、無職**（男）であ った。慆梗塞死では最大血圧*（ 女）のみであった。

心死では、最大血圧**（女）、 尿蛋白*（男）、E C G（高い $\mathrm{R}^{*}$ *、S T 変化**、 $\mathrm{T}$ 変化**)（女 ）、その他（以下、表略）、19 本以下の喫煙*（男）であった。 虚血性心疾患死では $\mathrm{S} \mathrm{H}^{*}$ （女）

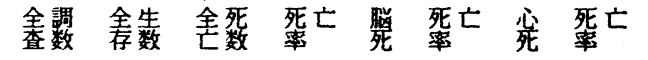

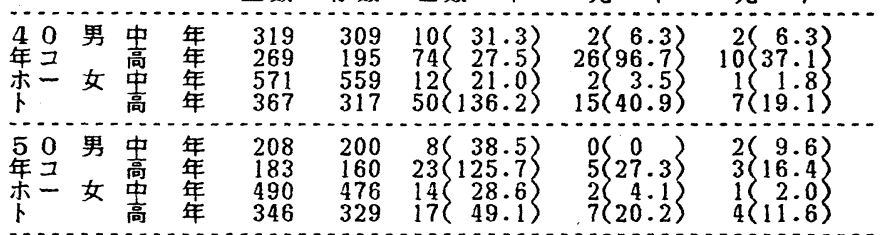

注：死亡率は対 1000 人、中年 $=30 \sim 49$ 歳、高年 $=50 \sim 69$ 歳 表 4

\begin{tabular}{|c|c|c|c|c|c|c|c|c|}
\hline & $\begin{array}{l}\text { 総 } \\
\text { 数 }\end{array}$ & $\begin{array}{l}\text { 死 死 } \\
\text { 数 } \\
\text { 索 }\end{array}$ & $\begin{array}{l}\mathrm{R} \\
\mathrm{R}\end{array}$ & 真 & 総 & $\begin{array}{ll}\text { 死 } & \text { 死 } \\
\text { 点 } \\
\text { 数 }\end{array}$ & $\begin{array}{l}\mathrm{R} \\
\dot{\mathrm{R}}\end{array}$ & 真 \\
\hline $\begin{array}{l}\sim 139 \\
140 \sim 159 \\
160 \sim 159\end{array}$ & $\begin{array}{r}118 \\
69 \\
82\end{array}$ & $\begin{array}{rr}10 & 8.5 \\
16 & 23.2 \\
19 & 23.7\end{array}$ & $\begin{array}{l}1.0 \\
2.7 \\
2.8\end{array}$ & $\begin{array}{l}* * \\
* * \\
* *\end{array}$ & $\begin{array}{l}136 \\
106 \\
125\end{array}$ & $\begin{array}{rr}7 & 5.1 \\
8 & 7.5 \\
19 & 15.2\end{array}$ & $\begin{array}{l}1.0 \\
1.5 \\
3.0\end{array}$ & $* *$ \\
\hline $\begin{aligned} & 89 \\
90 \sim & 99 \\
100 \sim & \end{aligned}$ & $\begin{array}{r}166 \\
58 \\
45\end{array}$ & $\begin{array}{ll}23 & 13.9 \\
11 & 19.0 \\
11 & 24.4\end{array}$ & $\begin{array}{l}1.0 \\
1.4 \\
1.8\end{array}$ & & $\begin{array}{r}233 \\
85 \\
49\end{array}$ & $\begin{array}{rr}15 & 6.4 \\
7 & 8.2 \\
12 & 24.5\end{array}$ & $\begin{array}{l}1.0 \\
1.3 \\
3.8\end{array}$ & ** \\
\hline $\bar{t} \sim \bar{t}+$ & $\begin{array}{r}253 \\
15\end{array}$ & $\begin{array}{rr}42 & 16.6 \\
3 & 20.0\end{array}$ & $\begin{array}{l}1.0 \\
1.2\end{array}$ & & $\begin{array}{r}333 \\
31\end{array}$ & $\begin{array}{rr}28 & 8.4 \\
5 & 16.1\end{array}$ & $\begin{array}{l}1.0 \\
1.9\end{array}$ & \\
\hline$\vec{\tau} \sim \overrightarrow{+}+$ & $\begin{array}{r}248 \\
20\end{array}$ & $\begin{array}{rr}45 & 18.1 \\
0 & 0\end{array}$ & & & $\begin{array}{r}357 \\
7\end{array}$ & $\begin{array}{rr}32 & 9.0 \\
1 & 14.3\end{array}$ & $\begin{array}{l}1.0 \\
1.6\end{array}$ & \\
\hline $\begin{array}{l}\text { S H H } \\
\text { S } \\
\text { S } \\
\text { H } 2\end{array}$ & $\begin{array}{r}159 \\
40 \\
46\end{array}$ & $\begin{array}{rr}22 & 13.8 \\
4 & 10.0 \\
13 & 28.3\end{array}$ & $\begin{array}{l}1.0 \\
0.7 \\
2.1\end{array}$ & $*$ & $\begin{array}{r}244 \\
39 \\
37\end{array}$ & $\begin{array}{rl}21 & 8.6 \\
0 & 0 \\
8 & 21.6\end{array}$ & $\begin{array}{l}1.0 \\
2.5\end{array}$ & \\
\hline $\begin{array}{l}S \text { S S } 0 \\
\text { S S } 1 \\
\text { S S } 2 \text { - }\end{array}$ & $\begin{array}{r}138 \\
80 \\
27\end{array}$ & $\begin{array}{rr}17 & 12.3 \\
14 & 17.5 \\
8 & 29.6\end{array}$ & $\begin{array}{l}1.0 \\
1.4 \\
2.4\end{array}$ & $*$ & $\begin{array}{r}186 \\
98 \\
36\end{array}$ & $\begin{array}{rr}14 & 7.5 \\
10 & 10.2 \\
5 & 13.9\end{array}$ & $\begin{array}{l}1.0 \\
1.4 \\
1.9\end{array}$ & \\
\hline $\begin{array}{l}10 \\
11,12,13 \\
31,33 \\
41,42,43 \\
51,52,53 \\
83\end{array}$ & $\begin{array}{r}150 \\
6 \\
76 \\
17 \\
17 \\
5\end{array}$ & $\begin{array}{rr}23 & 15.3 \\
1 & 16.7 \\
17 & 22.4 \\
5 & 29.4 \\
5 & 29.4 \\
2 & 40.0\end{array}$ & $\begin{array}{l}1.0 \\
1.1 \\
1.5 \\
1.9 \\
1.9 \\
2.6\end{array}$ & & $\begin{array}{r}214 \\
7 \\
77 \\
24 \\
32 \\
2\end{array}$ & $\begin{array}{rr}16 & 7.5 \\
1 & 14.3 \\
6 & 7.8 \\
3 & 12.5 \\
4 & 12.5 \\
2 & 100\end{array}$ & $\begin{array}{r}1.0 \\
1.9 \\
1.0 \\
1.7 \\
1.7 \\
13.3\end{array}$ & ** \\
\hline
\end{tabular}

注：EＣＧの数字はミネソタコード、高年 $=50 \sim 69$ 筬

有意差は各項自丙の歨常群との差、蜼 $\mathrm{P}<0.05$ 林は $\mathrm{P}<0.01$

表 5

$40 \sim 60$ 年コホー上の初年度検查所見别の心疾患死亡事

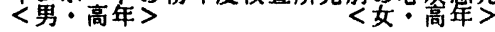

\begin{tabular}{|c|c|c|c|c|c|c|c|c|c|c|}
\hline & $\begin{array}{l}\text { 總 } \\
\text { 数 }\end{array}$ & 死 & $\begin{array}{l}\text { 死 } \\
\text { 率 }\end{array}$ & $\begin{array}{l}\mathrm{R} \\
\dot{\mathrm{R}}\end{array}$ & $\begin{array}{l}\text { 真 } \\
\text { 菪 }\end{array}$ & $\begin{array}{l}\text { 總 } \\
\text { 数 }\end{array}$ & & $\begin{array}{l}\text { 死 } \\
\text { 象 }\end{array}$ & $\begin{array}{l}\mathrm{R} \\
\dot{\mathrm{R}}\end{array}$ & $\begin{array}{l}\text { 真 } \\
\text { 意 }\end{array}$ \\
\hline $\mathrm{P}_{1140 \sim 159} \sim 139$ & $\begin{array}{r}118 \\
69 \\
82\end{array}$ & & $\begin{array}{r}7.6 \\
10.1 \\
11.0\end{array}$ & $\begin{array}{l}1.0 \\
1.3 \\
1.4\end{array}$ & & $\begin{array}{l}136 \\
106 \\
125\end{array}$ & $\begin{array}{r}6 \\
8 \\
18\end{array}$ & $\begin{array}{r}4.4 \\
7.5 \\
14.4\end{array}$ & $\begin{array}{l}1.0 \\
1.7 \\
3.3\end{array}$ & ** \\
\hline $\mathrm{P}_{100 \sim} \underset{90 \sim}{89}$ & $\begin{array}{r}166 \\
58 \\
45\end{array}$ & & $\begin{array}{r}9.0 \\
6.9 \\
13.3\end{array}$ & $\begin{array}{l}1.0 \\
0.8 \\
1.5\end{array}$ & & $\begin{array}{r}233 \\
85 \\
49\end{array}$ & & $\begin{array}{r}6.9 \\
11.8 \\
12.2\end{array}$ & $\begin{array}{l}1.0 \\
1.7 \\
1.8\end{array}$ & \\
\hline $\begin{array}{l}\mathrm{U} \\
\mathrm{P}\end{array} \overline{\sim+}+$ & $\begin{array}{r}253 \\
15\end{array}$ & $\begin{array}{r}21 \\
4\end{array}$ & $\begin{array}{r}8.3 \\
26.7\end{array}$ & $\begin{array}{l}1.0 \\
3.2\end{array}$ & $*$ & $\begin{array}{r}333 \\
31\end{array}$ & $\begin{array}{r}27 \\
5\end{array}$ & $\begin{array}{r}8.1 \\
16.1\end{array}$ & $\begin{array}{l}1.0 \\
2.0\end{array}$ & \\
\hline $\bar{t} \sim \bar{t}+$ & $\begin{array}{r}248 \\
20\end{array}$ & $\begin{array}{r}22 \\
3\end{array}$ & $\begin{array}{r}8.9 \\
15.0\end{array}$ & $\begin{array}{l}1.0 \\
1.7\end{array}$ & & $\begin{array}{r}357 \\
7\end{array}$ & $\begin{array}{r}30 \\
2\end{array}$ & $\begin{array}{r}8.4 \\
28.6\end{array}$ & $\begin{array}{l}1.0 \\
3.4\end{array}$ & \\
\hline $\begin{array}{ll} & \text { S H } \\
& \text { S H } \\
& \text { S } \\
& 2 \sim\end{array}$ & $\begin{array}{r}159 \\
40 \\
46\end{array}$ & $\begin{array}{r}16 \\
1 \\
4\end{array}$ & $\begin{array}{r}10.1 \\
2.5 \\
8.7\end{array}$ & $\begin{array}{l}1.0 \\
0.2 \\
0.9\end{array}$ & & $\begin{array}{r}244 \\
39 \\
37\end{array}$ & $\begin{array}{r}18 \\
4 \\
5\end{array}$ & $\begin{array}{r}7.4 \\
10.3 \\
13.5\end{array}$ & $\begin{array}{l}1.0 \\
1.4 \\
1.8\end{array}$ & \\
\hline 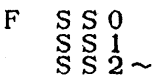 & $\begin{array}{r}138 \\
80 \\
27\end{array}$ & $\begin{array}{r}13 \\
5 \\
3\end{array}$ & $\begin{array}{r}9.4 \\
6.3 \\
11.1\end{array}$ & $\begin{array}{l}1.0 \\
0.7 \\
1.2\end{array}$ & & $\begin{array}{r}186 \\
98 \\
36\end{array}$ & $\begin{array}{r}17 \\
5 \\
5\end{array}$ & $\begin{array}{r}9.1 \\
5.1 \\
13.9\end{array}$ & $\begin{array}{l}1.0 \\
0.6 \\
1.5\end{array}$ & \\
\hline $\begin{array}{ll}\mathrm{E} & 10 \\
\mathrm{C} & 31,12,13 \\
\mathrm{G} & 41,42,43 \\
& 51,52,53 \\
& 83\end{array}$ & $\begin{array}{r}150 \\
6 \\
76 \\
17 \\
17 \\
5\end{array}$ & $\begin{array}{r}11 \\
1 \\
6 \\
3 \\
3 \\
0\end{array}$ & $\begin{array}{r}7.3 \\
16.7 \\
7.9 \\
17.6 \\
17.6 \\
0\end{array}$ & $\begin{array}{l}1.0 \\
2.3 \\
1.1 \\
2.4 \\
2.4\end{array}$ & & $\begin{array}{r}214 \\
7 \\
77 \\
24 \\
32 \\
2\end{array}$ & $\begin{array}{r}6 \\
1 \\
18 \\
7 \\
9 \\
0\end{array}$ & $\begin{array}{r}2.8 \\
14.3 \\
23.4 \\
29.2 \\
28.1 \\
0\end{array}$ & $\begin{array}{r}1.0 \\
5.1 \\
8.4 \\
10.4 \\
10.0\end{array}$ & \\
\hline
\end{tabular}

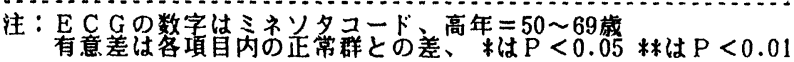




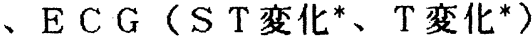
（女）であった。

4: 40 年及び 50 年コホートの リスク要因（表 $6 、 7 、 8 、 9 ）$

40 年コホートで正常群との間 に死亡率で有意差のあった項目は 、脳死では最大血圧**（男）、最 小血压*（男女）、 $\mathrm{S} \mathrm{H}^{* *}$ （男）

、 S S (男**女*)、E C G* ( S

$\mathrm{T}$ 変化、 $\mathrm{T}$ 変化）（男）、心死で は尿蛋白**（男）、E C G **（高 WR, S T 変化、 $\mathrm{T}$ 変化）（女） であった。

50 年コホートで正常群との間 に死亡率で有意差のあった項目は 脳死では最小血圧**（男）、尿 蛋白*（男）、尿糖**（女）、S $\mathrm{H}^{*}$ (男) $\mathrm{S} \mathrm{S}^{*}$ (男) $\mathrm{E} \mathrm{C} \mathrm{G}$ (高い $\mathrm{R}^{*} 、 \mathrm{~S} \mathrm{~T}$ 変化*、 $\mathrm{T}$ 変化** ）（男）、心死で注尿蛋白*（女 ）であった。

[考察]:

賀茂村におけるこの 20 年間の循 環器死亡の推移を死亡統計 ${ }^{1 、 2) よ ~}$ りみると、脳死については中年及 び高年で明らかな減少がみられた が、心死については減少傾向は明 らかではなかった。この間の高血 圧集団検診における各種所見の出 現状況の推移は、本研究の資料及 び今回の演者らの一般演題の報告 3)より、40 年代の急激なる軽症 化及び 50 年代のその傾向の鈍化 が明らかになった（次回に報告の
表 640 年コホートの初年度検查所見別の脳血管疾患死亡率 <男・高年>

総 死 死 $R$ 真 総 死 死 $R$ 直 数 数率 $\dot{\mathrm{R}}$ 意 数 数 率 $\dot{\mathrm{R}}$ 意

$\mathrm{S} \sim 139 \quad 118 \quad 2 \quad 1.7 \quad 1.0 \quad 136 \quad 5 \quad 3.7 \quad 1.0$

$\begin{array}{llllllllll}\mathrm{P} \quad 140 \sim 159 & 69 & 11 & 15.9 & 9.4 & * * & 106 & 2 & 1.9 & 0.5\end{array}$ $\begin{array}{llllllllll}160 \sim & 82 & 13 & 15.9 & 9.4 & * * & 125 & 8 & 6.4 & 1.7\end{array}$

D $\sim 2 \begin{array}{lllllllll}89 & 166 & 12 & 7.2 & 1.0 & 233 & 8 & 3.4 & 1.0\end{array}$

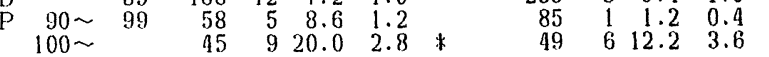

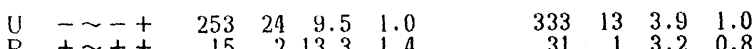

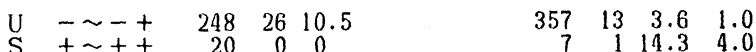

$\begin{array}{lllllllll}\mathrm{SHO} & 159 & 9 & 5.7 & 1.0 & 244 & 8 & 3.3 & 1.0\end{array}$

$\begin{array}{lllll}\mathrm{S} H \mathrm{H} & 40 & 2 & 5.0 & 0.9\end{array}$

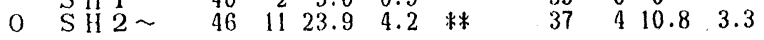

$\begin{array}{llllllllll}\text { F S S O } & 138 & 6 & 4.3 & 1.0 & 186 & 5 & 2.7 & 1.0\end{array}$

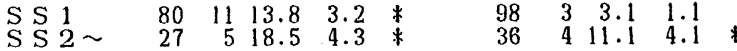

$\begin{array}{rlrrrrrrrrr} & 10 & 150 & 11 & 7.3 & 1.0 & & 214 & 8 & 3.7 & 1.0 \\ \mathrm{E} & 11,12,13 & 6 & 1 & 16.7 & 2.3 & & 7 & 1 & 14.3 & 3.9 \\ \mathrm{C} & 31,33 & 76 & 12 & 15.8 & 2.2 & & 77 & 2 & 2.6 & 0.7 \\ \mathrm{G} & 41,42,43 & 17 & 5 & 29.4 & 4.0 & * & 24 & 2 & 8.3 & 2.2 \\ & 51,52,53 & 17 & 5 & 29.4 & 4.0 & * & 32 & 2 & 6.3 & 1.7 \\ & 83 & 5 & 2 & 40.0 & 5.5 & 2 & 1 & 1.7 \\ \ldots\end{array}$

注：E C Gの数字はミネソタコ〜ド、高年 $=50 \sim 69$ 墄

有意差は各項目内の正常群との差、 *は $\mathrm{P}<0.05$ **は $\mathrm{P}<0.01$

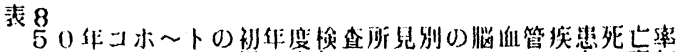
$<$ 男・高年>

<㚣・高年>

\begin{tabular}{|c|c|c|c|c|c|c|c|c|c|c|c|}
\hline & & 棇 & 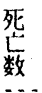 & $\begin{array}{l}\text { 死 } \\
\text { 率 } \\
.\end{array}$ & $\begin{array}{l}\mathrm{R} \\
\dot{\mathrm{R}}\end{array}$ & $\begin{array}{l}\text { 喑 } \\
\text { 差 } \\
\end{array}$ & 総 & 死 & $\begin{array}{l}\text { 死 } \\
\text { 率 }\end{array}$ & $\begin{array}{l}\mathrm{R} \\
\dot{\mathrm{R}}\end{array}$ & $\begin{array}{l}\text { 真 } \\
\text { 意 } \\
\text { 差 }\end{array}$ \\
\hline$\underset{\mathrm{P}}{\mathrm{S}}$ & $\begin{array}{l}140 \sim 139 \\
140 \sim 159 \\
160 \sim\end{array}$ & $\begin{array}{r}111 \\
45 \\
27\end{array}$ & & $\begin{array}{l}1.8 \\
0 \\
11.1\end{array}$ & $\begin{array}{l}1.0 \\
6.2\end{array}$ & & $\begin{array}{r}191 \\
84 \\
71\end{array}$ & $\begin{array}{l}3 \\
3 \\
1\end{array}$ & $\begin{array}{l}1.6 \\
3.6 \\
1.4\end{array}$ & $\begin{array}{l}1.0 \\
2.3 \\
0.9\end{array}$ & \\
\hline $\begin{array}{l}D \\
P\end{array}$ & $\begin{array}{r}\sim 89 \\
90 \sim 99 \\
100 \sim 9\end{array}$ & $\begin{array}{r}126 \\
36 \\
21\end{array}$ & & $\begin{array}{r}0.8 \\
2.8 \\
14.3\end{array}$ & $\begin{array}{r}1.0 \\
3.5 \\
17.9\end{array}$ & $* *$ & $\begin{array}{r}263 \\
59 \\
24\end{array}$ & $\begin{array}{l}6 \\
1 \\
0\end{array}$ & $\begin{array}{l}2.3 \\
1.7 \\
0\end{array}$ & $\begin{array}{l}1.0 \\
0.7\end{array}$ & \\
\hline$\stackrel{\mathrm{U}}{\mathrm{P}}$ & $\bar{t} \sim++$ & $\begin{array}{r}172 \\
10\end{array}$ & $\begin{array}{l}3 \\
2\end{array}$ & $\begin{array}{r}1.7 \\
20.0\end{array}$ & 11.8 & $*$ & $\begin{array}{r}329 \\
17\end{array}$ & $\begin{array}{l}7 \\
0\end{array}$ & 2.1 & & \\
\hline $\begin{array}{l}U \\
S\end{array}$ & $\bar{t} \sim \bar{t}+$ & $\begin{array}{r}165 \\
15\end{array}$ & $\begin{array}{l}5 \\
0\end{array}$ & $\begin{array}{l}3.0 \\
0\end{array}$ & & & $\begin{array}{r}339 \\
7\end{array}$ & $\begin{array}{l}5 \\
2\end{array}$ & $\begin{array}{r}1.5 \\
28.6\end{array}$ & $\begin{array}{r}1.0 \\
19.1\end{array}$ & ** \\
\hline 0 & $\begin{array}{l}\text { S H O } \\
\text { SH } 1 \\
\text { SH } 2 \sim\end{array}$ & $\begin{array}{r}130 \\
23 \\
8\end{array}$ & $\begin{array}{l}2 \\
1 \\
2\end{array}$ & $\begin{array}{r}1.5 \\
4.3 \\
25.0\end{array}$ & $\begin{array}{r}1.0 \\
2.9 \\
16.7\end{array}$ & $*$ & $\begin{array}{r}246 \\
36 \\
10\end{array}$ & $\begin{array}{l}2 \\
1 \\
0\end{array}$ & $\begin{array}{l}0.8 \\
2.8 \\
0\end{array}$ & $\begin{array}{l}1.0 \\
3.5\end{array}$ & \\
\hline$F$ & $\begin{array}{l}\text { S S } 0 \\
\text { S S } 1 \\
\text { S S } 2 \text { - }\end{array}$ & $\begin{array}{l}91 \\
59 \\
11\end{array}$ & & $\begin{array}{c}0 \\
5.1 \\
18.2\end{array}$ & & $*$ & $\begin{array}{r}198 \\
80 \\
14\end{array}$ & 1 & $\begin{array}{l}0.5 \\
1.3 \\
7.1\end{array}$ & $\begin{array}{r}1.0 \\
2.5 \\
14.2\end{array}$ & \\
\hline $\begin{array}{l}\mathrm{E} \\
\mathrm{C} \\
\mathrm{G}\end{array}$ & $\begin{array}{l}10 \\
11,12,13 \\
31,33 \\
41,42,43 \\
51,52,53 \\
83\end{array}$ & $\begin{array}{r}107 \\
5 \\
47 \\
13 \\
14 \\
4\end{array}$ & $\begin{array}{l}1 \\
1 \\
4 \\
2 \\
3 \\
0\end{array}$ & $\begin{array}{r}0.9 \\
20.0 \\
8.5 \\
15.4 \\
21.4 \\
0\end{array}$ & $\begin{array}{r}1.0 \\
22.2 \\
9.4 \\
17.1 \\
23.8\end{array}$ & $\begin{array}{l}* \\
* \\
* *\end{array}$ & $\begin{array}{r}203 \\
7 \\
59 \\
27 \\
31 \\
1\end{array}$ & $\begin{array}{l}3 \\
0 \\
2 \\
0 \\
1 \\
0\end{array}$ & $\begin{array}{l}1.5 \\
0 \\
3.4 \\
0 \\
3.2 \\
0\end{array}$ & $\begin{array}{l}1.0 \\
2.3 \\
2.1\end{array}$ & \\
\hline
\end{tabular}

注：ECGの数字はミネソタコ〜ド、高年=50〜69藏

有意差は各項目内の正常群との差、*结 $\mathrm{P}<0.05$ 枕 $\mathrm{P}<0.01$ 予定）。これらの背景として栄義摂取状況をみてみると、20 年前は大部分の栄美

（魚類の蛋白と塩分を除く）は全国值を下回っていたが、現在ではその全てが全国值 を上回るまでになっていた ${ }^{4)}$ 。このような生活環境の変貌の中で、今回明らかになっ た循環器疾患のリスク要因の変化を理解する必要があると考える。

[結語]：

1）：脳死及心死の死亡率は、中年に比し高年に有意に高かった。性差はなかった。 
50 年コホートの男の脳死は 40 年コホートに比し有意に少なかっ た。

2)：40〜60 年コホート研究 より、脳死は血圧の関与が大きく 有意差あり、眼底についても有意 差があった。心電図上では心房細 動汇有意差があった。心死は血圧 の関与は小さく、眼底の関与はみ られなかった。心電図上では高い $\mathrm{R} 、 \mathrm{~S} \mathrm{~T}$ 変化、 $\mathrm{T}$ 変化に有意差が あった。

3)：40 年コホート、50 年コ ホートの比較検討より、脳死では 血圧と眼底の関与がやや軽くなり 、心電図はやや重くなった。心死 では血圧と眼底の関与は殆どなく 、心電図の有意差がなくなったが 、尿蛋白に有意差を認めるように なった。

[参考文献]：

1)桂 敏樹他：日本公衛誌、30、4 37,1983

2)野尻雅美他：日農医誌、33、883 , 1985

3)野尻雅美他：本学会、一般演題 、114席

4)野尻雅美他：日本公衛誌、32、6 94,1985

本研究は中野正孝氏（千葉大学 看護学部) 及びこの間の旧松崎保 健所（合併後の下田保健所）長と の共同研究をまとめたものです。 資料提供及び調查に協力いただい た賀茂村住民課の皆様に感謝しま す。
表 7 40 年コホートの初年度梌查所見别の心㾤患死亡事

\begin{tabular}{|c|c|c|c|c|c|c|c|c|c|c|c|}
\hline & & 数 & 点 & 死 & $\begin{array}{l}\mathrm{R} \\
\dot{\mathrm{R}}\end{array}$ & $\begin{array}{l}\text { 惪 } \\
\text { 意 }\end{array}$ & 数 & 死 & $\begin{array}{l}\text { 死 } \\
\text { 率 }\end{array}$ & $\begin{array}{l}\mathrm{R} \\
\dot{\mathrm{R}}\end{array}$ & $\begin{array}{l}\text { 真 } \\
\text { 意 } \\
\text { 差 }\end{array}$ \\
\hline$\underset{\mathrm{P}}{\mathrm{S}}$ & $\begin{array}{l}140 \sim 139 \\
160 \sim 159 \\
160 \sim\end{array}$ & $\begin{array}{r}118 \\
69 \\
82\end{array}$ & $\begin{array}{l}4 \\
2 \\
4\end{array}$ & $\begin{array}{l}3.4 \\
2.9 \\
4.9\end{array}$ & $\begin{array}{l}1.0 \\
0.9 \\
1.4\end{array}$ & & $\begin{array}{l}136 \\
106 \\
125\end{array}$ & 5 & $\begin{array}{l}0.7 \\
0.9 \\
4.0\end{array}$ & $\begin{array}{l}1.0 \\
1.3 \\
5.7\end{array}$ & \\
\hline D & $\begin{array}{r}\sim 89 \\
100 \sim 99\end{array}$ & $\begin{array}{r}166 \\
58 \\
45\end{array}$ & $\begin{array}{l}7 \\
1 \\
2\end{array}$ & $\begin{array}{l}4.2 \\
1.7 \\
4.4\end{array}$ & $\begin{array}{l}1.0 \\
0.4 \\
1.0\end{array}$ & & $\begin{array}{r}233 \\
85 \\
49\end{array}$ & $\begin{array}{l}5 \\
1 \\
1\end{array}$ & $\begin{array}{l}2.1 \\
1.2 \\
3.3\end{array}$ & $\begin{array}{l}1.0 \\
0.6 \\
1.6\end{array}$ & \\
\hline $\mathrm{U}$ & $-\sim \sim+t$ & $\begin{array}{r}253 \\
15\end{array}$ & $\begin{array}{l}6 \\
4\end{array}$ & $\begin{array}{r}2.4 \\
26.7\end{array}$ & $\begin{array}{l}1.0 \\
11.1\end{array}$ & $* *$ & $\begin{array}{r}333 \\
31\end{array}$ & $\begin{array}{l}6 \\
1\end{array}$ & $\begin{array}{l}1.8 \\
3.2\end{array}$ & $\begin{array}{l}1.0 \\
1.8\end{array}$ & \\
\hline $\begin{array}{l}U \\
S\end{array}$ & $\ddot{+\sim r+t}+$ & $\begin{array}{r}248 \\
20\end{array}$ & $\begin{array}{l}9 \\
1\end{array}$ & $\begin{array}{l}3.6 \\
5.0\end{array}$ & $\begin{array}{l}1.0 \\
1.4\end{array}$ & & $\begin{array}{r}357 \\
7\end{array}$ & 0 & 2.0 & & \\
\hline 0 & $\begin{array}{l}\text { S H } \\
\text { H } \\
\text { H } \\
\text { H } 2\end{array}$ & $\begin{array}{r}159 \\
40 \\
46\end{array}$ & $\begin{array}{l}6 \\
1 \\
1\end{array}$ & $\begin{array}{l}3.8 \\
2.5 \\
2.2\end{array}$ & $\begin{array}{l}1.0 \\
0.7 \\
0.6\end{array}$ & & $\begin{array}{r}244 \\
39 \\
37\end{array}$ & $\begin{array}{l}3 \\
0 \\
2\end{array}$ & $\begin{array}{l}1.2 \\
0 \\
7.7\end{array}$ & $\begin{array}{l}1.0 \\
6.4\end{array}$ & \\
\hline $\mathrm{F}$ & 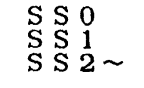 & $\begin{array}{r}138 \\
80 \\
27\end{array}$ & $\begin{array}{l}5 \\
1 \\
2\end{array}$ & $\begin{array}{l}3.6 \\
1.3 \\
7.4\end{array}$ & $\begin{array}{l}1.0 \\
0.4 \\
2.1\end{array}$ & & $\begin{array}{r}186 \\
98 \\
36\end{array}$ & $\begin{array}{l}3 \\
2 \\
0\end{array}$ & $\begin{array}{l}1.6 \\
2.0 \\
0\end{array}$ & $\begin{array}{l}1.0 \\
1.3\end{array}$ & \\
\hline & $\begin{array}{l}10 \\
11,12,13 \\
31,33 \\
41,42,43 \\
51,52,53 \\
83\end{array}$ & $\begin{array}{r}150 \\
6 \\
76 \\
17 \\
17 \\
5\end{array}$ & $\begin{array}{l}2 \\
1 \\
2 \\
1 \\
1 \\
0\end{array}$ & $\begin{array}{r}1.3 \\
16.7 \\
2.6 \\
5.9 \\
5.9 \\
0\end{array}$ & $\begin{array}{r}1.0 \\
12.8 \\
2.0 \\
4.5 \\
4.5\end{array}$ & & $\begin{array}{r}214 \\
7 \\
77 \\
24 \\
32 \\
2\end{array}$ & $\begin{array}{l}1 \\
0 \\
5\end{array}$ & $\begin{array}{c}0.5 \\
0 \\
6.5 \\
20.8 \\
15.6 \\
0\end{array}$ & $\begin{array}{r}1.0 \\
13.0 \\
41.6 \\
31.2\end{array}$ & $\begin{array}{l}* * \\
* *\end{array}$ \\
\hline
\end{tabular}

注：E C G の数字はミネソタコ〜ド、高年 $=50 \sim 69$ 藏

有意差は各項目内の正常群との差、杖 $\mathrm{P}<0.05 * *$ * $\mathrm{P}<0.01$ 表 9 50 年コポトの初年度検查所見別の心疾態死亡等 <男・高年〉 <女・高年〉

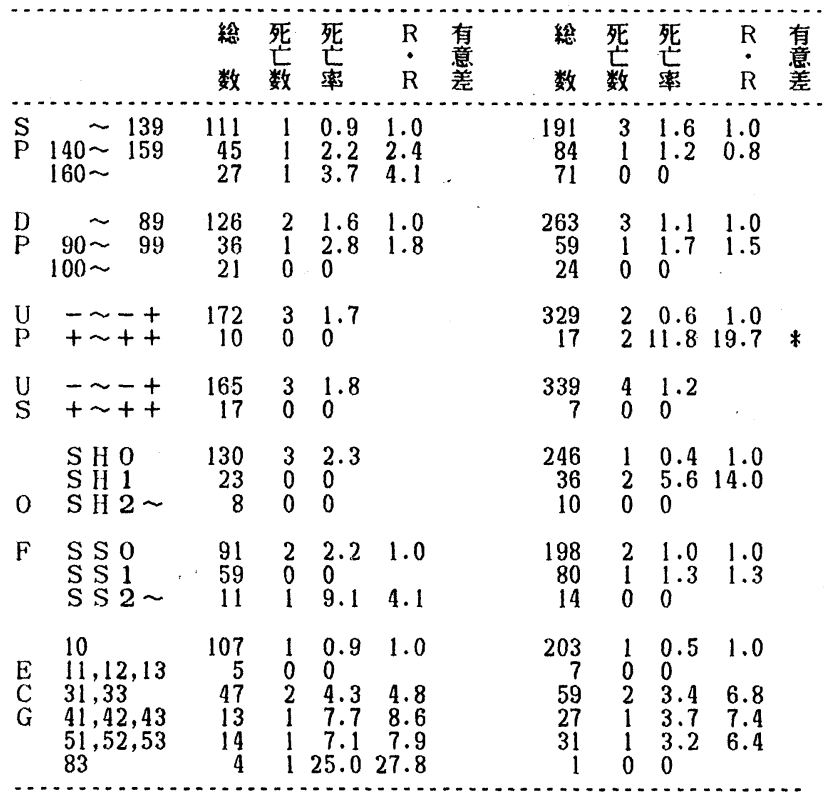

注：EＣＧの数字はミネソタコード、高年 $=50 \sim 69$ 歳 有意差は各項目内の正常群との差、数 $\mathrm{P}<0.05$ ** 


\section{佐久地域における脳卒中実態調查}

長野県佐久地域《人口約 10 万 6 千人》では、WHO国際拹同研究として地域内 全住民を対象とした脳卒中発症者の全例登録と追跡調査を行ったが、昭和47年か ら 4 年間の発症登録者は994人に達し、人口10万対の年間発症率は2 36 である。

病型別頻度をみると、表 1 のどとく、脳出血 $27.1 \%$, 脳梗塞 $59.8 \%$, クモ膜下出 出 $9.5 \%$, 分類不明の脳卒中 $3.7 \%$ ある。男女別飞発症率をみると、脳卒中全体 では男が女の1.20倍であるが、脳出血は1.29倍, 脳梗塞は1.16倍、クモ膜下出血 は1.42倍であり、梗塞より出血群において性差が著しい。

年齢別飞発症状況をみると、最す多い年代は70才代で $35.5 \%$ を占め、ついで 60

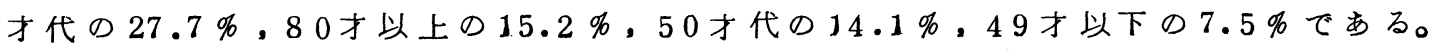

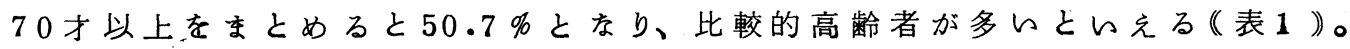

月別飞発症状況をみると、図 1 のどとく、冬から春先に多発しているが、病型 別にみると脳出血は 4 月と 11 月にビークを示し、脳梗塞では 1 月から4月にかけ て多かった。佐久地域は寒冷地であって4月はまだ肌寒い日が多く、三寒四温と

表 1 佐久地域における脳卒中発应状況

（昭和 47 年 4 月～51年 3 月）

\begin{tabular}{|c|c|c|c|c|c|c|c|}
\hline & 総数（年 & 発症率） & ～49藏 & $50 \sim 59$ & $60 \sim 69$ & $70 \sim 79$ & $80 \sim$ \\
\hline \multirow{3}{*}{ 総 数 } & 994 & (236) & 75 & 140 & 275 & 353 & 151 \\
\hline & 527 & $(259)$ & 56 & 84 & 143 & 187 & 57 \\
\hline & 467 & $(216)$ & 19 & 56 & 132 & 166 & 94 \\
\hline \multirow[t]{3}{*}{ 脳 出 血 } & 269 & $(64)$ & 35 & 39 & 76 & 82 & 37 \\
\hline & 147 & $(72)$ & 26 & 23 & 40 & 42 & 16 \\
\hline & 122 & $(56)$ & 9 & 16 & 36 & 40 & 21 \\
\hline \multirow[t]{3}{*}{ 脳 梗 塞 } & 594 & (141) & 25 & 70 & 169 & 229 & 101 \\
\hline & 310 & (152) & 19 & 39 & 88 & 128 & 36 \\
\hline & 284 & (131) & 6 & 31 & 81 & 101 & 65 \\
\hline \multirow[t]{3}{*}{ クモ膜下出血 } & 94 & $(22)$ & 13 & 30 & 21 & 28 & 2 \\
\hline & 54 & ( 27$)$ & 10 & 21 & 10 & 12 & 1 \\
\hline & 40 & ( 19$)$ & 3 & 9 & 11 & 16 & 1 \\
\hline 分類不明の脳卒中 & 37 & $(9)$ & 2 & 1 & 9 & 14 & 11 \\
\hline 男 & 16 & $(8)$ & 1 & 1 & 5 & 5 & 4 \\
\hline 女 & 21 & $(10)$ & 1 & - & 4 & 9 & 7 \\
\hline
\end{tabular}

注）発症率は，昭和50年度国驁調査人口による 
らわれる温度差が激しい。と らした春秋の季節変動期の温 度差が血王の変動飞影響し、 高血圧と最す関連の梁的脳出 血発症の誘因になっていると 考えられる《(図1》。

脳卒中発症前の高血王の有 無および治療状況をみると、 図2のでとく、脳出血では 69 才以下の「高血圧あり」が 67 \%，「なし」が13\%，「不明」

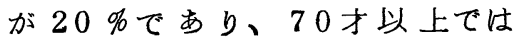
「高血圧あり」が $88 \%$ 「なし」 が $6 \%$ ，「不明」が $6 \%$ と王倒 的飞高血圧の既往が多い。脳 血栓飞おいてる、69才以下で は「高血殴あり」が79\%、「な

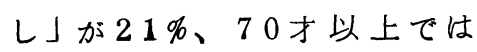

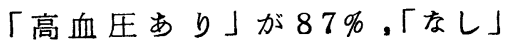

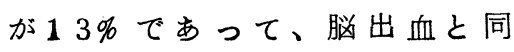
様に高率である。脳卒中発症 前の高血殴治療状況をみると、脳出血においては 69 才以下，70才以上の両群と と治療中断および放置のるのが治療中に比べて明らかに多い。しかしながら、脳 血栓では69才以下においては治療中断および放置が多いが、70才以上では治療 中.との差は認められない《図2 )。

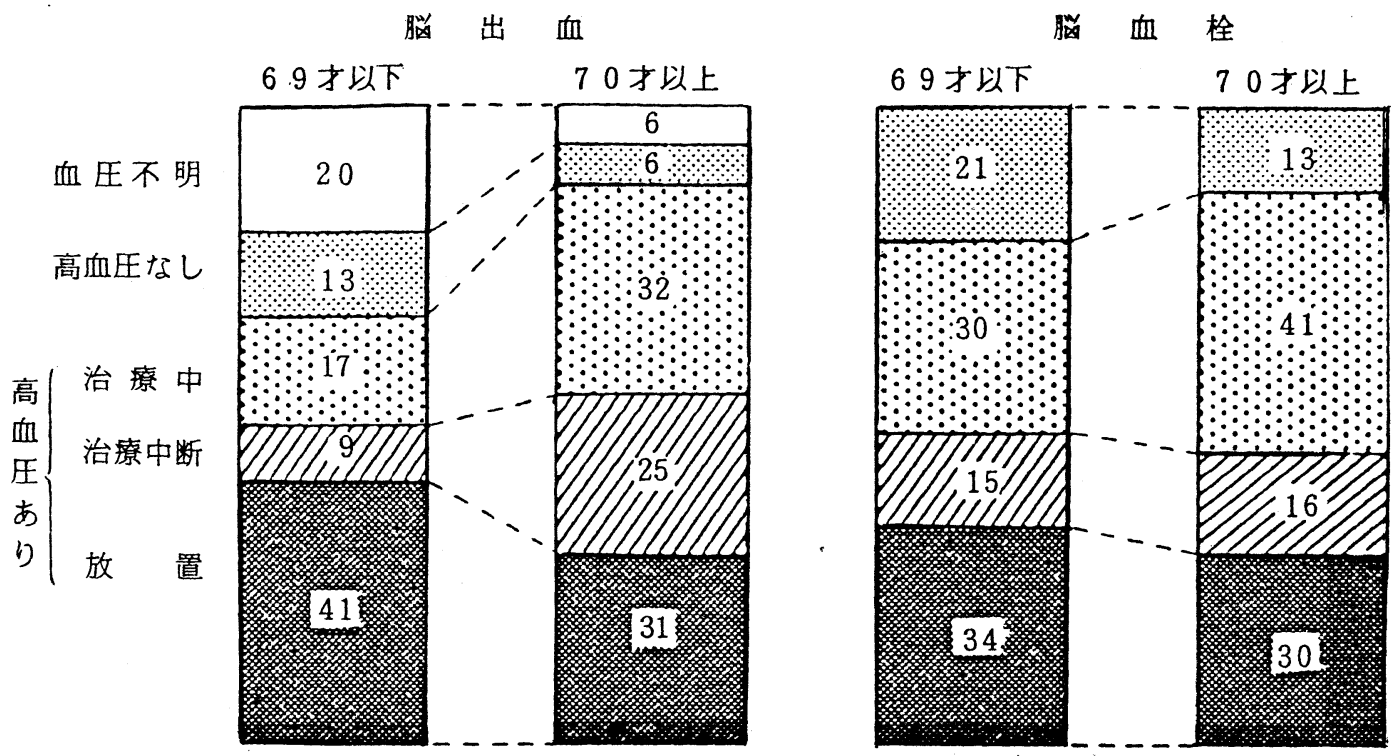

図 2 脳出血・知血栓発症前高血王の有無と治亦状況

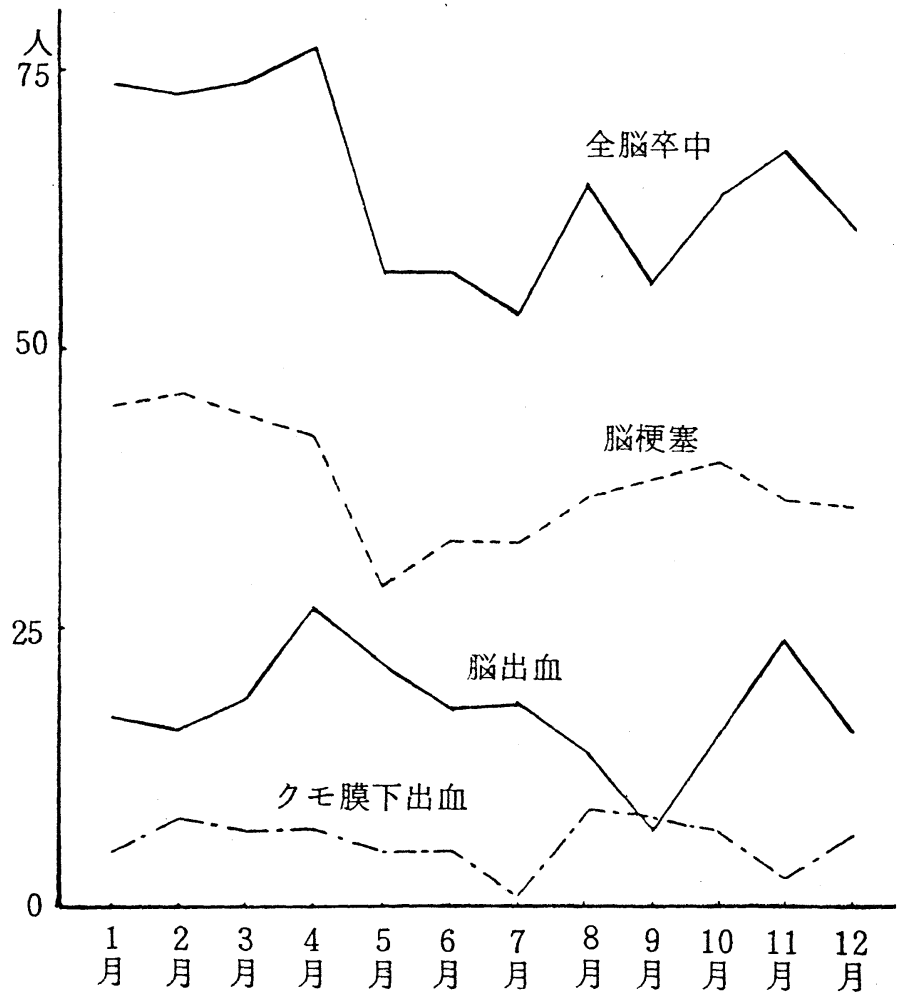

図 1 病型別・月別脳卒中発症状況 


\section{T 䀰断による病型分類}

佐久地域の脳卒中入院患者の約 $70 \%$ 入院している佐久総合病院において、CT を含む諸検査に上る最終診断の病型分類をみると、昭和 50 万 51 年度の脳卒中入院 患者《初回発作のみ》462例のうち脳出血は119例《25.8\%》), 脳梗塞は260 例 $((56.3 \%)$, クモ膜下出血は 67 例《 $14.5 \%)$, 小脳出血, 小脳梗塞はそれぞれ8例 《1.7\%》であった。てれを前述した佐久地域の脳卒中発症調査と比較すると。ク モ膜下出血の頻度が佐久総合病院の症例において多いが、その理由は脳神経外科 が佐久地域では佐久総合病院しかないてとが関与していると考えられる。

10 年後の昭和 60 年度におらて、再び C T 検査に上る脳卒中病型別頻度を検討 した。ただし今回は脳出血と脳梗塞につんてのみ集計し、再発例も含めた。検討 した症例は 515 例であるが病型別頻度をみると、脳出血 108 例《 $21.0 \% 》$, 脳梗塞 204 例 ( $39.6 \%)$, 多発性脳梗塞 179 例 ( $34.8 \%)$, 小脳出血と小脳梗塞がそれぞれ 12 例《( $2.3 \%)$ ある。多発性脳梗塞を除いた 336 例について病型別頻度をみると、 脳出血 $32.1 \%$, 脳梗塞 $60.7 \%$, 小脳出血と小脳梗塞が各 $3.6 \%$ となり 10 年前の 結果と大差はない。単発の脳梗塞のなかで小梗塞は $51.9 \%$ となり多的。多発性 脳梗塞は予想以上飞高率にみられたが、そのらち多発性小梗塞が $68.7 \%$ と約 $2 / 3$ に達している。

\section{地域における脳卒中予防管理}

佐久地域の一山間農村である八千穂村では、昭和 34 年以降全村健康管理を継続 実施しているが、そのなかから循環器障害の実態を検討した。まず、肥满者の推 移を 40 〜 69 才の年代についてみると、男の60才代を除を全般に肥满者加増加 してをている。なお、10 年前には 50 才，60才代の女においてのみ增加がみられた。

つぎに血清コレステロール平均值の12 年間の推移をみると、表 2 のでとく、各 年代とる上算してをているが、とくに最近において上昇傾向が著しい。性・年代 別飞みると、50才，60才代の女において上昇が目立っている《表 2 》。

表2 コレステロールレベルの推移

$<八 千$ 穂村：昭和 45 年〜 57 年 $>$

$(\mathrm{mg} / \mathrm{d} 1)$

\begin{tabular}{|c|c|c|c|c|c|c|c|c|c|}
\hline & \multirow{2}{*}{$\begin{array}{r}\text { 年鉿 } \\
(才)\end{array}$} & \multicolumn{2}{|c|}{$40 \sim 49$} & \multicolumn{2}{|c|}{$50 \sim 59$} & \multicolumn{2}{|c|}{$60 \sim 69$} & \multicolumn{2}{|c|}{$70 \sim 79$} \\
\hline & & 平均値 & 樽準偏差 & 平均値 & 標準偏差 & 平均値 & 標準偏差 & 平均値 & 標準偏差 \\
\hline \multirow{4}{*}{ 男 } & 昭和 45 年 & 175.6 & 31.5 & 176.7 & 27.6 & 175.8 & 28.6 & 174.0 & 25.5 \\
\hline & 49 & 182.0 & 34.6 & 176.5 & 28.9 & 173.4 & 27.3 & 171.3 & 26.0 \\
\hline & 53 & 179.4 & 31.1 & 181.7 & 33.1 & 174.4 & 33.7 & 172.4 & 3 3.7 \\
\hline & 57 & 194.2 & 34.2 & 200.1 & 40.9 & 190.5 & 31.1 & 187.6 & 37.1 \\
\hline \multirow{4}{*}{ 女 } & 45 & 172.6 & 28.5 & 193.5 & 32.7 & 191.7 & 31.1 & 189.0 & 33.2 \\
\hline & 49 & 174.2 & 29.9 & 194.6 & 32.9 & 192.0 & 30.6 & 184.2 & 32.3 \\
\hline & 53 & 176.5 & 33.0 & 199.7 & 35.1 & 199.1 & 35.9 & 185.9 & 34.5 \\
\hline & 57 & 189.4 & 33.6 & 214.5 & 34.8 & 217.5 & 36.9 & 203.4 & 39.1 \\
\hline
\end{tabular}


高血压者の推移をみると、頻度においては大をな変化はないが高度高血压者が 減少し、血圧平均值す、とくに最大血圧の低下が著しい。

脳卒中予防の管理効果の指標として最重要な脳卒中発症数の推移を、昭和 34 年から 45 年までの管理前期と、昭和 46 年から 57 年までの管理後期飞分けてみる と、前期の発症数は 241 人《男 133 人,女108人》であったが、後期には167人

(男 86 人,女 81 人)となり $30.7 \%$ の減少率を示した。

近年、農村では都市以上飞急速に人口の高齢化が進んでいるが、高齢者人口が 增加すればする 质ど高齢者に多 発する脳卒中の 発症者。增加し て当然である。

そこで前期は 昭和 40 年, 後期 は昭和 50 年の国 勢調查人口に。 とづんて、人口 1000 人対の年 代別発症率を比 較した。その結 果図3に示すご とく、全年代で低 下しており、とく に 70 才以上の高 齢者での低下が 著しい((図3)。
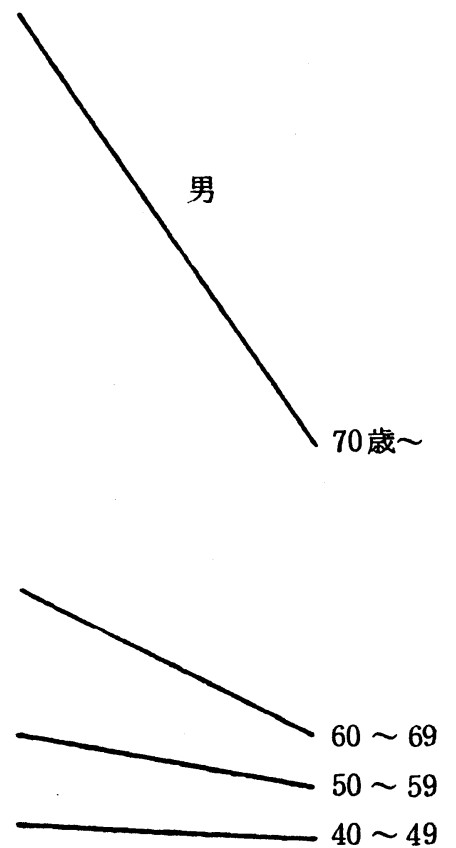

前期
後期

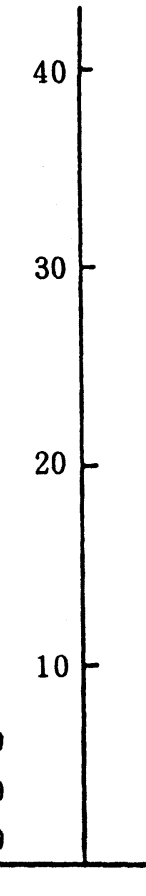

前期
前期：昭和 34 年 45 年 後期：昭和 46 年 57 年

人口 1,000 対

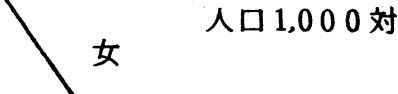

図 3 脳卒中年代別発症率の推移《八千穂村》

\section{まとめ}

(1) 佐久地域での脳卒中調査から、病型別頻度は医脳出血 3 , 脳梗塞 6 , ク モ膜下出血1の比である。月別発症状況をみると冬から春先にかけて多発してい るが、脳出血では4月と11月の季節変動期にピークを示している。発症前の高血 现の既往は脳出血，脳血栓とも高率にみられ、また治療中断ないし放置群が多い。 しかし、70才以上の脳血栓におらては治療群との差は認められなかった。

(2) 佐久総合病院飞おけるC T 検査飞上る病型分類調査加 、、病型別頻度は地 域調查の結果と大差はない。近年、多発性脳梗塞がかなり多くみられる上らにな り。昭和 60 年度の調査では $34.8 \%$ 《そのうち小梗塞が約 $2 / 3 》$ と高率である。

(3) 八千穂村全村健康管理の実態加 、肥满者壮各年代とす增加し、血清総 コ レステロールる上界傾向を示している。しかし、長期にわたる高血压管理に上っ て脳卒中発症数は $30.7 \%$ 减少し、年代別発症率では70才以上の低下が著しい。 
関口善孝

(広島県厚生連広島総合病院)

\section{はじめに}

わが国の脳血管障害による死亡は近年減少傾向にあるとはいうものの，日常臨床 の場で働きざかりの人々が不幸な転機をとったり，重篤な後遺症の残るような発 作を扟てことを㯪々経験する。従って，その発症を予知出来れば対応策を考え るととあ可能であると思われる。以上のととをふまえて, 発症前の臨床検査成績 を調查し，その予知が可能であるかを検討した。

\section{対象と方法}

昭和 51 年 4 月より実施している広島県内の成人病検診受診者のうち, 脳卒中を 発症し，功発症前 1 年以内の検査成績の得られた症例と，昭和 59 年・60年に当 科 ICUに収容し, 発症前 1 年以内の検査成績の得られた症例の男 61 例 • 女 31 例の 計 92 例を全脳卒中とし, 昭和 59 年成人 病検診受診者の中加ら, 脳卒中発症例 を除いた男 606 例・女 1381 例の計 1987 例在対照群とした(表 1)。ICU 収容者 は頭部 C T・脳血管写などにより出血

・硬塞に分類したが，検診受診者から

\begin{tabular}{|c|c|c|c|c|c|c|c|c|c|c|}
\hline & \multicolumn{3}{|c|}{ 男 } & \multicolumn{2}{|l|}{ 性 } & \multicolumn{3}{|c|}{ 女 } & \multicolumn{2}{|l|}{ 性 } \\
\hline & $\begin{array}{l}40 \sim \\
49 才\end{array}$ & $\begin{array}{l}50 \sim \\
59 才\end{array}$ & $\begin{array}{l}60 \sim \\
69 \text { 才 }\end{array}$ & $\begin{array}{l}70 \text { 才 } \\
\text { 以上 }\end{array}$ & 計 & $\begin{array}{l}40 \sim \\
49 才\end{array}$ & $\begin{array}{l}50 \sim \\
59 \text { 才 }\end{array}$ & $\begin{array}{l}60 \sim \\
69 \text { 才 }\end{array}$ & $\begin{array}{l}70 \text { 才 } \\
\text { 以上 }\end{array}$ & 計 \\
\hline 全脳卒中 & 6 & 6 & 18 & 31 & 61 & 2 & 11 & 6 & 12 & 31 \\
\hline 脳 硬 塞 & 3 & 1 & 9 & 20 & 33 & 0 & 2 & 3 & 9 & 14 \\
\hline 脳出 血 & 1 & 2 & 3 & 6 & 12 & 0 & 3 & 2 & 1 & 6 \\
\hline 対 照 群 & 131 & 170 & 160 & 41 & 606 & 404 & 519 & 272 & 31 & 1381 \\
\hline
\end{tabular}

の発症例はアンケート調査に基ずいてなされたため病型分類は不可能であり，全 脳卒中に加えて検討した。

脂質・血糖・尿酸・尿素窒素・クレアチニン・総蛋白・アルブリンはAutoanalyzer で測定し，血色素はCoulter Counterで，BMIは身長・体重より算定し，血圧は安 静仰臥位で水銀血圧計を用いて測定した。心電図はフクダFCP-130を用いて安 静仰臥位で標準 12 誘導を記録した。

\section{成}

1) $\mathrm{BMI}$

（図 1 - 表 2) 男では全脳卒 中が有意に低 値を，女では 有意差はない が高値をとり,

\section{加高值をとり。} $\begin{array}{llll}\text { 目 } & \text { B } & \text { M } & \text { I }\end{array}$

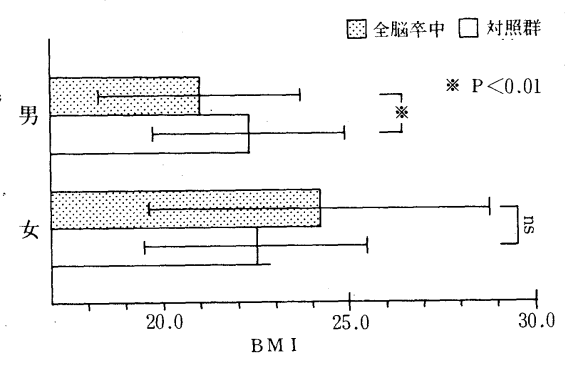

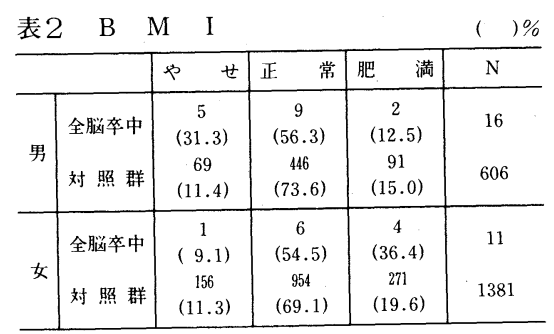
女では肥満者から脳卒中の発症の多いことがうかがわれた。

2)収縮期血圧（図2）。男女各年代とあいずれの病型であ有意飞高值であり， 
汹2 收維 期 血 1 :

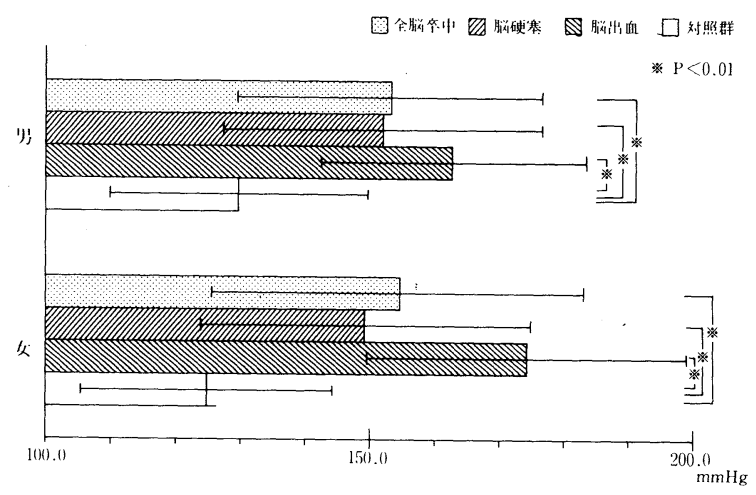

とくに出血で著るしかった。

3）拡張期血圧（図 3）。70才以上の女の全脳卒中 • 硬塞を除くと, 性別年令別にみても脳卒中例が高值を 示した。表 3 は各群の $\mathrm{WHO}$ 基準による高血圧頻度を みたものであるが, 男女とあ高血王者からの脳卒中発 症頻度は高く，とくに出血で高率であった。
汹3 搪拈期 血 11:

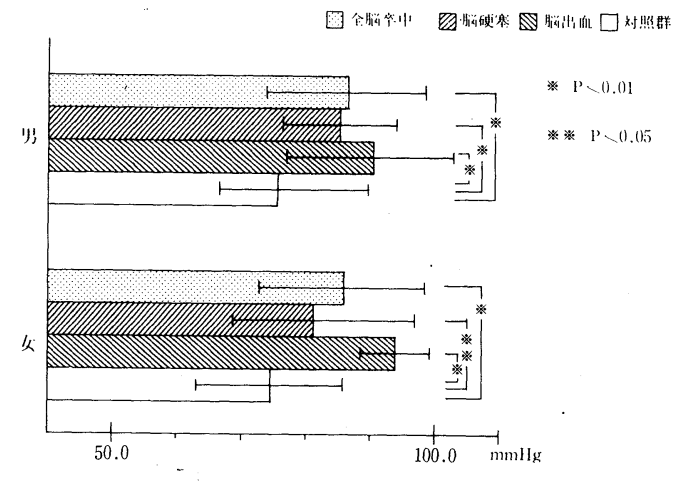

\begin{tabular}{|c|c|c|c|c|}
\hline & 男 性 & $\mathrm{N}$ & 女 性 & $\mathrm{N}$ \\
\hline 全綗卒中 & $\begin{array}{c}25 \\
(41.0)\end{array}$ & 61 & $\begin{array}{c}16 \\
(51.6)\end{array}$ & 31 \\
\hline 脳 硬 塞 & $\begin{array}{c}12 \\
(36.4)\end{array}$ & 33 & $\begin{array}{c}6 \\
(42.9)\end{array}$ & 14 \\
\hline 脳 & $\begin{array}{c}6 \\
(50.0)\end{array}$ & 12 & $\begin{array}{c}4 \\
(66.7)\end{array}$ & 6 \\
\hline 对 目 & $\begin{array}{c}74 \\
(12.2)\end{array}$ & 606 & $\begin{array}{l}120 \\
(8.7)\end{array}$ & 1381 \\
\hline
\end{tabular}

4) 総コレステロール(図 4) 。男の全脳卒中が有意に高值であったが, 他には 有意差は認められなかった。220 mg/dl以上と $140 \mathrm{mg} / d \ell$ 以下に分けてみると， 低コレ群からの脳卒中発症頻度は対照群亡差はないが，高コレ群からのそれは， 男女とくに男で脳卒中で明らかに多く，硬塞が出血よりあ明らかであった。

刚4 総コレステロール

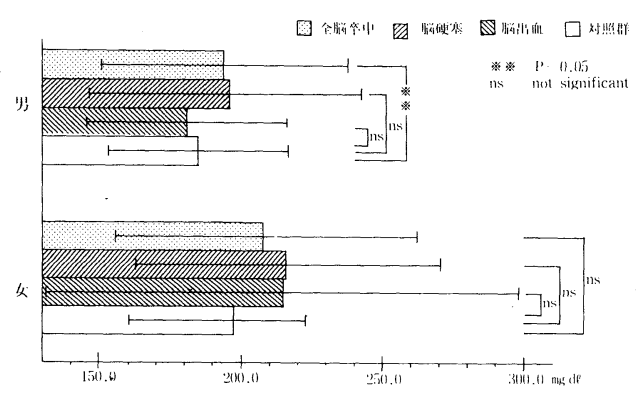

5) 中性脂肪（図 5 ）。男女脳卒中例が 高值を示したが, とくに女は各病型とも 有意に高值であった。 $150 \mathrm{mg} / \mathrm{dl}$ 以上を 示す者は脳卒中群で多く，とくに出血で 明らかであり，女に多くみられた。

6）血色素（図6）。男は脳卒中群が有 意に低值・女は高值を示したが, 男 13.0 $g / d \ell$ 以下 - 女 $12.0 \mathrm{~g} / \mathrm{d} \ell$ 以下加らの脳卒中 発症頻度は対照群よりも明らかに多く,
冈1 5 中性脂肪

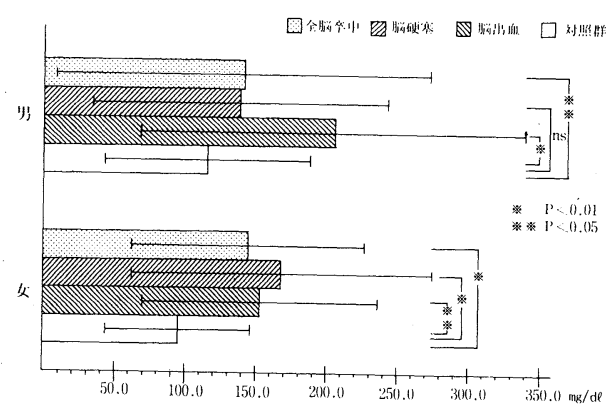

汹6 血. 色当

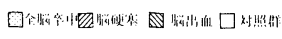

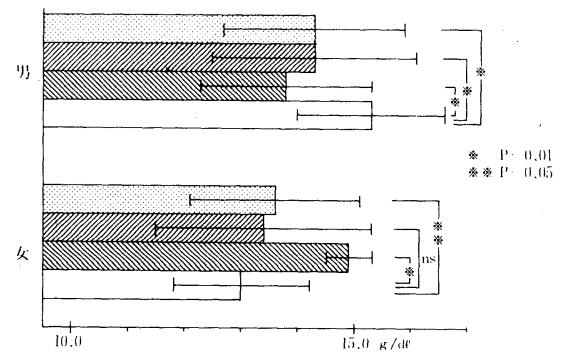




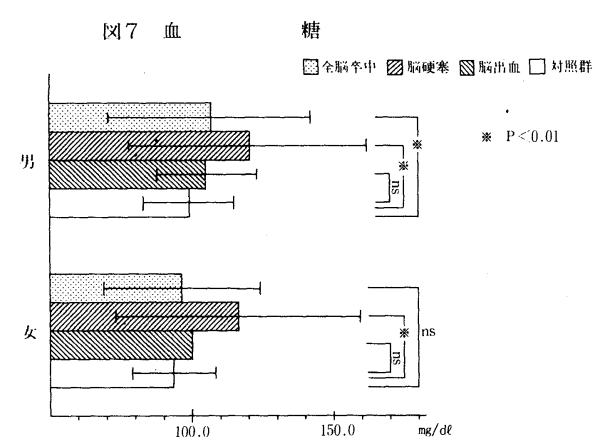

とくに男の出血で著明であった。

7）血糖（図 7 ）。男の全脳卒中 - 硬塞 で有意差がみられ，女は硬塞だけに認め

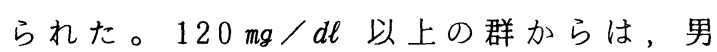
女とあ硬塞が多く発症していた。

8)尿酸（図8）。男女いずれの病型之 あ有意に高值であった。 $8.0 \mathrm{mg} / \mathrm{d \ell}$ 以上の 例からは男の出血が明らかに多く発症し

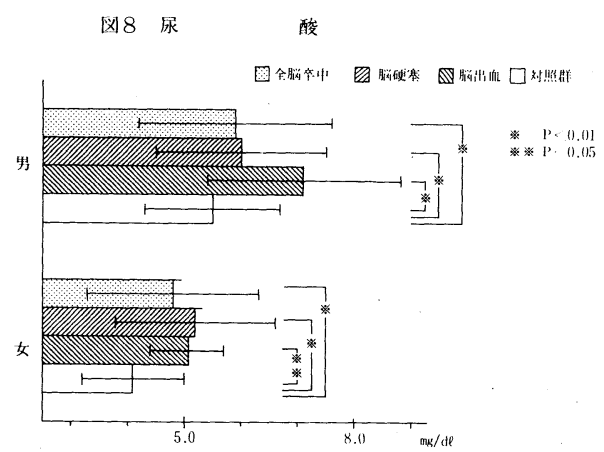

図9 血清総蛋白

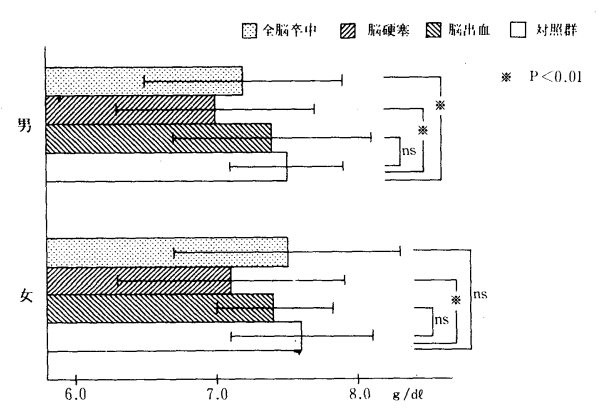

ていたd

9）総蛋白（図9）。全脳卒中では男で有意に低值を示し，硬塞では男女とも有 意飞低值であった。 $8.0 \mathrm{~g} / \mathrm{dl}$ 以上と $6.5 \mathrm{~g} / \mathrm{dl}$ 以下の群からの発症頻度をみると， 高值群からは男の出血が多く認められた以外は対照群よりあ低率であった。一方, 低值群からの出血発症は 1 例もなかったが, 男女とあ硬塞は著るしく多く発症し, とくに女では顕著であった。

10)アルブミン（図10）。全脳卒中・硬塞で男女とも有意に低值であった。3.5 $g / d \ell$ 以下からは男女とあ硬塞が多く発症していた。

11) 尿素窒素（図11）。男女と屯脳卒中群が有意に高く，20 mg/dl以上の群から は硬塞が多く発症し,とくに女で明らかであった。

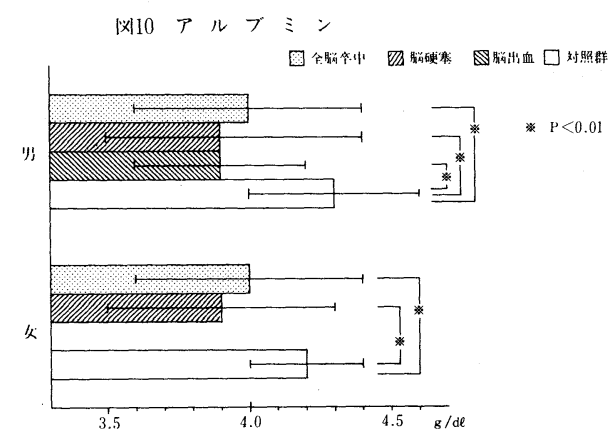

図11 尿素窒 素

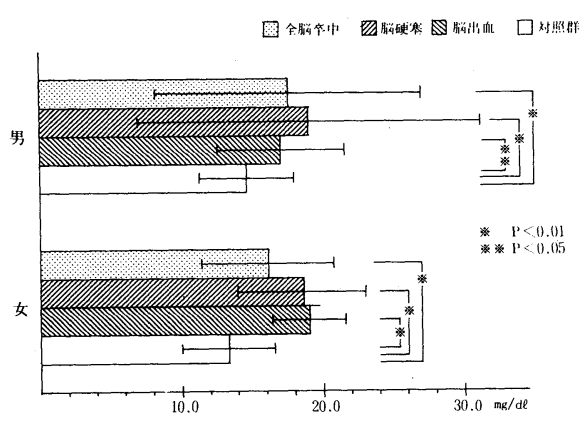


12)クレアチニン（図12）。女の出血を 除いた群で有意に高值であり， $1.5 \mathrm{mg} / \mathrm{d \ell}$ 以上の例からは女の硬塞が多く発症してて いた。
汹12クレアチニン

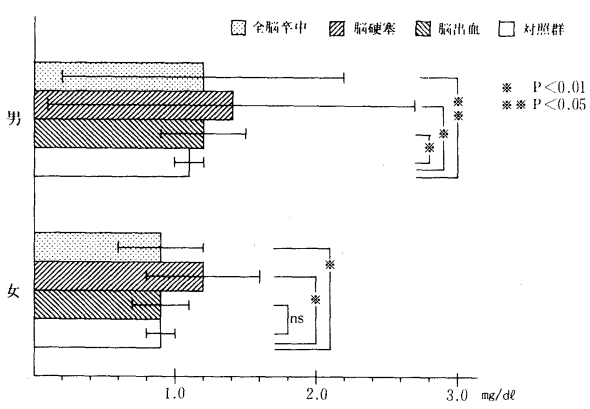

\begin{tabular}{|c|c|c|c|c|c|c|c|c|c|c|c|c|c|c|}
\hline & & $\begin{array}{l}\text { 让 } \\
\mathrm{I}-0 \\
\end{array}$ & $\begin{array}{c}\text { 異常 Q } \\
\mathrm{I} \\
\end{array}$ & $\begin{array}{c}\text { Q R S } \\
\text { 高電位 } \\
\text { III }\end{array}$ & $\begin{array}{cc}S & T \\
\text { 低 } & \text { 下 } \\
& \\
& \\
\end{array}$ & $\begin{array}{c}\mathrm{T} \text { 異常 } \\
\mathrm{V} \\
\end{array}$ & $\begin{array}{c}\text { 房室ブ } \\
\text { ロック } \\
\text { VI } \\
\end{array}$ & $\begin{array}{cr}L & B \\
B & B \\
\text { VII } & -1 \\
\end{array}$ & $\begin{array}{lr}\mathrm{R} & \mathrm{B} \\
\mathrm{B} & \mathrm{B} \\
\mathrm{VII} & -2\end{array}$ & $\begin{array}{l}\text { 期 } \text { 外 } \\
\text { 収 縮 } \\
\text { VIII }-1\end{array}$ & $\begin{array}{ll}\text { 心 房 } \\
\text { 細 動 } \\
\text { VIII }-3 \\
\end{array}$ & $\begin{array}{l}\text { 頻 脈 } \\
\text { VIII }-7 \\
\end{array}$ & $\begin{array}{l}\text { 徐 脈 } \\
\text { VIII }-8\end{array}$ & $\begin{array}{l}\text { パー } \\
\text { シング } \\
\text { VIIII-9 }\end{array}$ \\
\hline \multirow{4}{*}{ 男 } & 全脳卒中 & 24.4 & 3.9 & 12.8 & 19.2 & 15.4 & 6.4 & 1.3 & 2.6 & 1.3 & 9.0 & 1.3 & 0 & 2.6 \\
\hline & 脳 硬 塞 & 23.8 & 2.4 & 9.5 & 21.4 & 16.7 & 2.4 & 0 & 2.4 & 2.4 & 14.3 & 0 & 0 & 4,8 \\
\hline & 滺出 血 & 21.4 & 0 & 21.4 & 21.4 & 21.4 & 7.1 & 0 & 0 & 0 & 0 & 7.9 & 0 & 0 \\
\hline & 対 照 群 & 66.2 & 2.4 & 9.1 & 13.9 & 8.2 & 5.3 & 0.1 & 2.8 & 0.3 & 1.0 & 1.3 & 5.1 & 0 \\
\hline \multirow{4}{*}{ 女 } & 全脳卒中 & 18.9 & 1.9 & 11.3 & 17.0 & 30.2 & 0 & 0 & 3.8 & 5.7 & 7.6 & 1.9 & 1.9 & 0 \\
\hline & 脳 硬塞 & 21.8 & 4.4 & 4.4 & 26.0 & 21.8 & 0 & 0 & 0 & 13.0 & 8.7 & 0 & 0 & 0 \\
\hline & 脸出血 & 14.3 & 0 & 14.3 & 14.3 & 14.3 & 0 & 0 & 14.3 & 0 & 14.3 & 14.3 & 0 & 0 \\
\hline & 対 照 群 & 66.2 & 0.8 & 3.5 & 17.9 & 12.8 & 1.1 & 0.1 & 0.8 & 0.4 & 0.2 & 2.5 & 1.3 & 0 \\
\hline
\end{tabular}

13）心電図所見（表 4）。男女と屯心房細動 - T 波異常 - Q R S 高電位 - 異常 $\mathrm{Q}$ 波からの全脳卒中発症の頻度が高かった。病型別には若干の差はみられたが, 異 常 $\mathrm{Q}$ 波・頻発する期外収縮は硬塞例だけにみられ，QR S 高電位は出血例に多く みられた。

\section{まこめ}

脳卒中患者の発症前 1 年以内の臨床検査成績を検討し以下の結果を得た。

1）男女とあ収縮期血圧・拡張期血圧の上昇，尿酸值上昇，低アルブミン血，尿 素窒素上昇，心電図異常（心房細動・ T 波異常・QR S 高電位・異常 $\mathrm{Q}$ 波）の る者からの脳卒中発症が多かった。その他に，男はやせて貧血があり，低蛋白血 症や高血糖を示す者から，女は肥満者で中性脂肪が高值を示し，クレアチニンの 上昇している者から脳卒中が多く発症していた。

2）病型別には脳硬塞は高血圧・高血糖・低蛋白・低アルブミン血・腎機能障害 例から，脳出血は高血圧・高中性脂肪血・男の貧血から発症していた。

今後は今回認められた異常りスク群を治療是正することにより，脳卒中発症が 如何に抑えられるかを追求していかなければならない。 
腷卒中の遠隔予知と近接予知

$\bigcirc$ 進藤多妃子，伊藤 政志

(秋田県厚生連由利組合総合病院)

\section{〔はじめに〕}

脳卒中は昭和 26 年に死因の首位を占めて以来人口構成の高令化が進む中で 増えつづけ、昭和 41 年には腷卒中死亡率は全国が 10 万対 124 人に対して秋田県 192 人、由利地区 215 人で、我々の診療地域は有数の脳卒中多発地带であった。 しかし近年、脳卒中死亡は着実に減少傾向をたどり、ついに昭和 56 年は首位の 坐を癌にゆずり、昭和 59 年には3 位にまで下がり、全国が 10 万対 65 人、秋田 県 72 人で由利地区は 66 人と約 1/3に激減し、全国レベルに達した。この間我 々は昭和 43 年に地域保健活動部を設置し、循環器検診を行い、脳卒中予防のた めに、生活指導 ・栄養指導・高血压治療の指導を行ってきた。今回我々は、検 診時の検查成績より、脳卒中発生の予知の可能性について、10 年後の遠隔予知 と、1 年以内発生の近接予知について検討したので報告する。

\section{(対象と方法)}

昭和 47 年 7 月から 10 月末日までの 偱環器検診受診者のうち、検診時年令 40 才から 69 才までの男 1239 人、女 1484 人、計 2723 人を対象とし、検診 直後から昭和 48 年 10 月 31 日までに発症した者を 1 年以内発症者、昭和 56 年 12 月 31 日までに発症した者を 10 年以内発症者とした。検診内容は、血圧・心 電図・眼底検查で採血検査は行っていない。追跡調査は主に各地域の保健婦に依頼した。

\section{[結果]}

(1) 性因子について：10 年以内発症者は 232 人 $(8.5 \%)$ 、男 122 人 ( $9.8 \%)$ 女 110 人 $(7.4 \%)$ で、男:女 $=4: 3$ 。 1 年以内発症者は 32 人 ( $1.3 \%)$ 、男 19 人( $1.5 \%)$ 女 13 人 $(0.9 \%)$ 男:女 $=5: 3$ 。

(2) 年令因子について（表 1、図1）：40代の10年以内発症 31 人 (3.2\%) 1 年以内 3 人 $(0.3 \%) 、 50$ 代は各々 108 人 $(10.4 \%) 13$ 人 (1.3\%)、60代は93 人 $(13.3 \%) 16$ 人 $(2.7 \%) 。 40$ 代を基準としてその発生比率を見ると、10 年以内は $1: 3: 4 、 1$ 年以内は $1: 4: 9$ で高令者ほど早期に発症することが明 らかであった。

(3)血压因子について（表 2、図 2)：血压レベルを139/89.以下か 200/120 以上までの 5 段階に分けて検討した。139/89以下の正常血圧群の発生率を 1 とすると、血圧レベルの上昇にしたがって、10 年以内は1:1.3:1.7:2.7: 6 と段階的に危険度が高まり、200/120以上群の危険度は6倍で非常に高 い。1 年以内発症では、1:1.1:2.3:6:15.5 で 180/110以上群からの危険 度は急激に高くなり、200/120以上群は極端に高く 15.5 倍にも達し、更に 同群の発症者の $1 / 4$ が 1 年以内に発症している。 
(4) 年代別・血圧群別脳卒中発生率（表3、図3・3’）：40代は発症者が少い ため検討に致らなかった。50 代では、各血压レベルにしたがって 10 年以内 発生比率は $1: 1.3: 1.7: 2.8: 5.6$ で連続的に危険率が増大する。 1 年以内は 1 : 0:1.5:4:16で 180/110以上群から急激に不連続的に増大し、200/120 以上群ではその $40 \%$ が 1 年以内に発症していた。60代では、10 年以内発 生比率は1:1:1.2:1.6:2.5で危険率の増大は非常にゆるやかである。これ に対して 1 年以内は1:4:6:9:14で、140/90の境界血圧群から既に危険 度の增大は急勾配であり、10 年以内とは全く異った態度を示した。

(5) 心電図所見別脳卒中発生率 (表 4、図 4) : 正常群、1-High R 群、ST. T 変 化群、1-High R + ST. T変化群、1ーHigh R + Strein T 群の 5 群に分類した。 正常群を基準とした発生比率は、10 年以内が $1: 1.3: 2: 2.5: 5.5$ に対し、1 年以内は $1: 2.3: 2: 6.5: 20$ で、いづれもStrein T 危険度は高く、High R のみ、ST. T変化のみの危険度は低い。

(6) 眼底変化と脳卒中発生率 (表5、図5)：KW0・ $\mathrm{I}^{\circ} \cdot \mathbb{I}^{\circ}$ 以上の3 群に分類し た。0を基準とした発生比率は 10 年以内が $1: 2.7: 5.2 、 1$ 年以内は $1: 3:$ 7 で、いづれも眼底変化とともに危険度は高くなるが、両者間に有意差はない。 (7) パターン別脳卒中発生率（表6、図6)：血圧・心電図・眼底の3因子を組合 せ、8つのパターンに分類した。危険因子０の群と高血圧のみを有する群と比 較すると 1 年以内はどちらも $0.5 \%$ で差はない。しかし 10 年以内は高血圧を 有する群は 2 倍の発生率であった。眼底変化群と眼底変化十高血圧群の比較 では、1年以内・10 年以内ともに後者が 2 倍で差はなかった。心電図変化群 と心電図変化十高血圧群では、10 年以内発生率は $12.9 \% 、 12.8 \%$ と全く同 率であったが、1年以内発生率は $1.1 \% \rightarrow 5.2 \%$ で高血压を伴うことによって 5 倍に増大した。眼底変化十心電図変化群と眼底変化十心電図変化十高血圧群 では、10 年以内は後者が 1.5 倍、1 年以内では前者が 0 に対し後者が $9 \%$ で 最も高い発生率を示し、非常に興味深い結果を得た。

[考察]

昭和 47 年の腯環器検診成績をもとに受診者の 10 年間の追跡調查を行い、1 年以内の脳卒中発症者と 10 年以内発症者の危険因子について比較検討を行っ た。

高血圧は 1 年以内発症により高いRiskを認め、180/110を越えると急激に 発生率が高まる。高令者では、10 年以内発生率に対する血圧のRisk は各レべ ルでゆるやかに増加を示したが、1年以内発生率は各レベルで急勾配で増加し た。心電図変化も高度なほど早期発症傾向著明で、特にStreinTの危険度は高 い。眼底変化は10 年・1年両者間に大きな差はない。パターン分類を行ってみ ると、高血圧の影響は 1 年以内発症者に強く認め、臓器障害を伴うとそれは更 に増大した。 
表 1 年代別脳卒中発生率

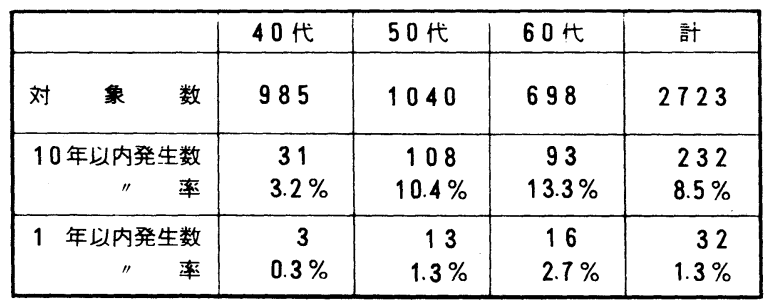

表 2 血圧群別脳卒中発生率

\begin{tabular}{|c|c|c|c|c|c|}
\hline $\begin{array}{l}\text { 收縮期血圧 } \\
\text { 拡張期血坧 }\end{array}$ & $\begin{array}{r}\sim 139 \\
\sim \quad 89\end{array}$ & $\begin{array}{r}140 \sim \\
90 \sim\end{array}$ & $\begin{array}{r}160 \sim \\
95 \sim\end{array}$ & $\begin{array}{l}180 \sim \\
110 \sim \\
\end{array}$ & $\begin{array}{l}200 \sim \\
120 \sim \\
\end{array}$ \\
\hline 対 象 数 & 1168 & 710 & 568 & 233 & 43 \\
\hline $\begin{array}{r}10 \text { 年以内発生数 } \\
\text { 発生率 }\end{array}$ & $\begin{array}{r}68 \\
5.8 \%\end{array}$ & $\begin{array}{r}55 \\
7.7 \%\end{array}$ & $\begin{array}{c}57 \\
10 \%\end{array}$ & $\begin{array}{c}36 \\
15.5 \%\end{array}$ & $\begin{array}{r}15 \\
35 \%\end{array}$ \\
\hline $\begin{array}{r}1 \text { 年以内発生数 } \\
\text { 発生率 }\end{array}$ & $\begin{array}{r}7 \\
0.6 \%\end{array}$ & $\begin{array}{r}5 \\
0.7 \%\end{array}$ & $\begin{array}{r}8 \\
1.4 \%\end{array}$ & $\begin{array}{c}8 \\
3.4 \%\end{array}$ & $\begin{array}{r}4 \\
9.3 \%\end{array}$ \\
\hline
\end{tabular}

表 3 年代別 - 血圧群別脳卒中発生率

\begin{tabular}{|c|c|c|c|c|c|}
\hline $\begin{array}{l}\text { 收縮期血圧 } \\
\text { 搪張斯血圧 }\end{array}$ & $\begin{array}{r}-139 \\
\sim \quad 89\end{array}$ & $\begin{array}{r}140 \sim 159 \\
90 \sim 94\end{array}$ & $\begin{aligned} 160 & \sim 179 \\
95 & \sim 109\end{aligned}$ & $\begin{array}{l}180 \sim 199 \\
110 \sim 119\end{array}$ & $\begin{array}{l}200 \sim \\
120 \sim\end{array}$ \\
\hline 対 象 数 & 504 & 233 & 180 & 59 & 9 \\
\hline 10 年以内発生 & $11(2.2)$ & $8(3.4)$ & $6 \quad(3.3)$ & $2(3.4)$ & $3(33.3)$ \\
\hline 1 年以内発生 & $1(0.2)$ & $1(0.4)$ & (0) & $1(1.7)$ & $(0)$ \\
\hline 50 代 対 象 数 & 447 & 276 & 213 & 84 & 20 \\
\hline 10 年以内発生 & $32(7.2)$ & $25(9.1)$ & $26(12.2)$ & $17(20.2)$ & $8(40.0)$ \\
\hline 1 年以内発生 & $4(0.9)$ & $0 \quad(0)$ & $3(1.4)$ & $3(3.6)$ & $3(15.0)$ \\
\hline 60 代 対 象 数 & 218 & 201 & 175 & 90 & 14 \\
\hline 10 年以内発生 & $25(11.5)$ & $22(11.0)$ & $25(14.3)$ & $17(18.9)$ & $4(28.6)$ \\
\hline 1 年以内発生 & $2(0.5)$ & $4(2.0)$ & $5 \quad(2.9)$ & $4(4.4)$ & $1 \quad(7.1)$ \\
\hline
\end{tabular}

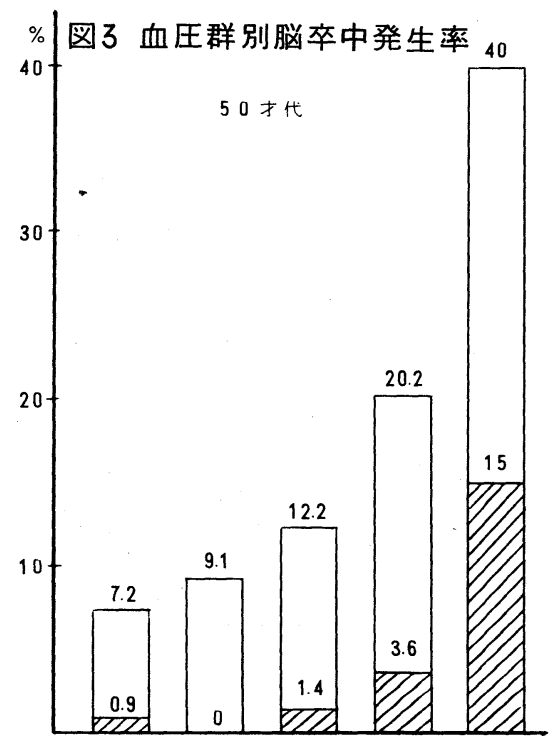

収縮期血圧 〜139 140 159 160 179 180 199 200

拡張期血圧 $\sim 89 \quad 95 \sim 94 \quad 95 \sim 109 \quad 110 \sim 119 \quad 120 \sim$
図 1 年代別脳卒中発生率
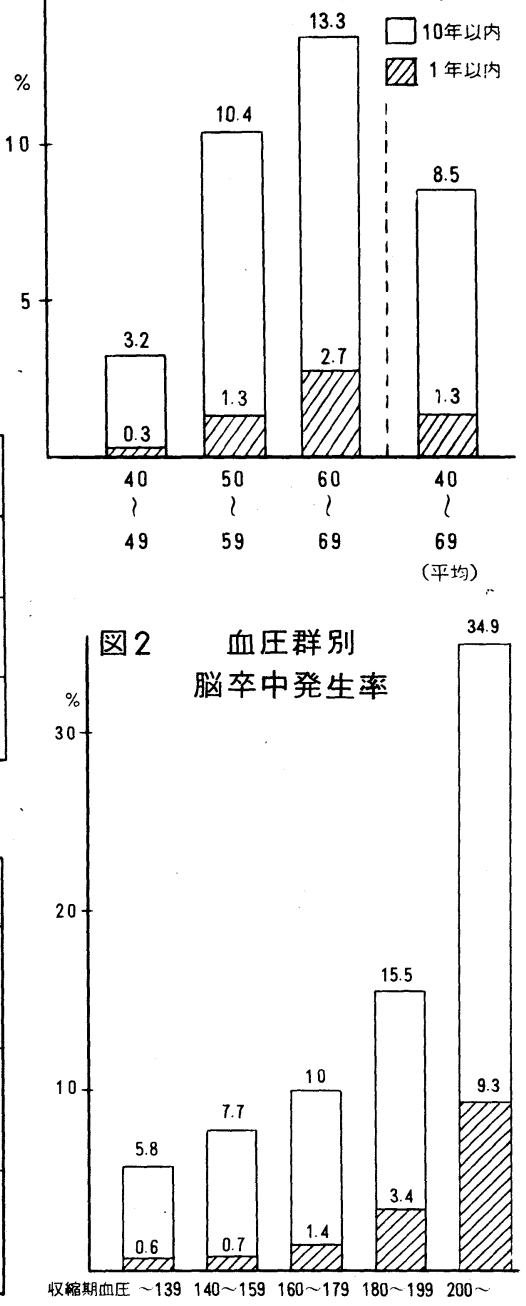

胎張期血圧 $\sim 89 \quad 90 \sim 94 \quad 95 \sim 109 \quad 110 \sim 119 \quad 120 \sim$

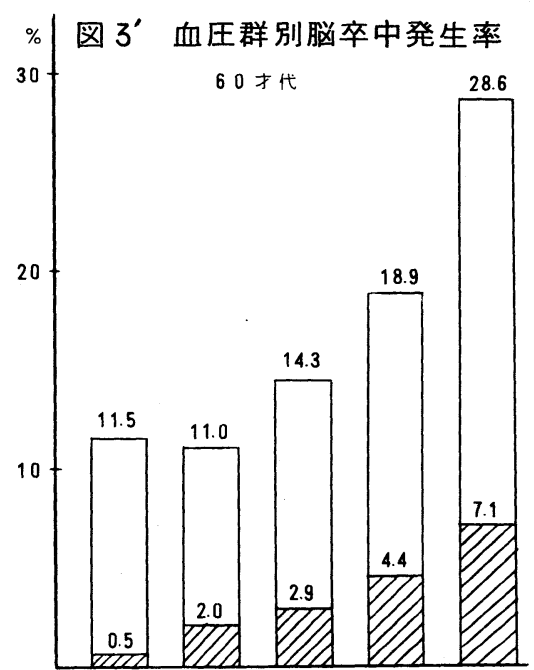

収縮期血圧 139 140 159 160 179 180 199 200

拡張期血圧 $\sim 89 \quad 90 \sim 94 \quad 95 \sim 109 \quad 110 \sim 119 \quad 120 \sim$ 
表4 心電図所見別脳卒中発生率

\begin{tabular}{|c|c|c|c|c|c|}
\hline & 正 常 & $\ell-H$ igh-R & S.T.T.変化 & $\begin{array}{l}\ell-H i g h R \\
\text { +STT変化 }\end{array}$ & $\begin{array}{l}\ell-\text { High R } \\
+ \text { Strain T }\end{array}$ \\
\hline 対 象 数 & 1362 & 489 & 410 & 156 & 33 \\
\hline $\begin{array}{r}10 \text { 年以内発生数 } \\
\text { 発生率 }\end{array}$ & $\begin{array}{r}85 \\
6.2 \%\end{array}$ & $\begin{array}{c}37 \\
7.6 \%\end{array}$ & $\begin{array}{r}49 \\
12 \%\end{array}$ & $\begin{array}{c}24 \\
15.4 \%\end{array}$ & $\begin{array}{c}11 \\
33.3 \%\end{array}$ \\
\hline $\begin{array}{r}1 \text { 年以内発生数 } \\
\text { 発生率 }\end{array}$ & $\begin{array}{r}8 \\
0.6 \%\end{array}$ & $\begin{array}{c}7 \\
1.4 \%\end{array}$ & $\begin{array}{r}5 \\
1.2 \%\end{array}$ & $\begin{array}{c}6 \\
3.8 \%\end{array}$ & $\begin{array}{c}4 \\
12.1 \%\end{array}$ \\
\hline
\end{tabular}

表 5 眼底所見亡脳卒中発生率

\begin{tabular}{|c|c|c|c|}
\hline $\mathrm{K}-\mathrm{W}$ & 0 & I & II 以上 \\
\hline 対 象 数 & 1588 & 928 & 144 \\
\hline $\begin{array}{r}10 \text { 年以内発生数 } \\
" 1 \text { 率 }\end{array}$ & $\begin{array}{r}57 \\
3.6 \%\end{array}$ & $\begin{array}{c}89 \\
9.6 \%\end{array}$ & $\begin{array}{r}27 \\
18.8 \%\end{array}$ \\
\hline $\begin{array}{r}1 \text { 年以内発生数 } \\
\prime \prime \quad \text { 率 }\end{array}$ & $\begin{array}{r}8 \\
0.5 \%\end{array}$ & $\begin{array}{c}13 \\
1.4 \%\end{array}$ & $\begin{array}{r}5 \\
3.5 \%\end{array}$ \\
\hline
\end{tabular}

表 6 パターン別脳卒中発生率

\begin{tabular}{|c|c|c|c|c|c|c|c|}
\hline & 心電図変化 & 眼底変化 & 対象数 & \multicolumn{2}{|c|}{10 年以内発生 } & \multicolumn{2}{|c|}{1 年以内発生 } \\
\hline 非 & - & - & 1068 & 48 & $4.5 \%$ & 5 & $0.5 \%$ \\
\hline 高 & - & + & 45 & 4 & 8.9 & 1 & 2.2 \\
\hline 仕 & + & - & 272 & 35 & 12.9 & 3 & 1.1 \\
\hline 群 & + & + & 12 & 2 & 16.7 & 0 & 0 \\
\hline 高 & - & - & 413 & 39 & 9.4 & 2 & 0.5 \\
\hline 血 & - & + & 46 & 8 & 17.4 & 2 & 4.3 \\
\hline 纴 & + & - & 172 & 22 & 12.8 & 9 & 5.2 \\
\hline 群 & + & + & 44 & 11 & 25 & 4 & 9 \\
\hline
\end{tabular}

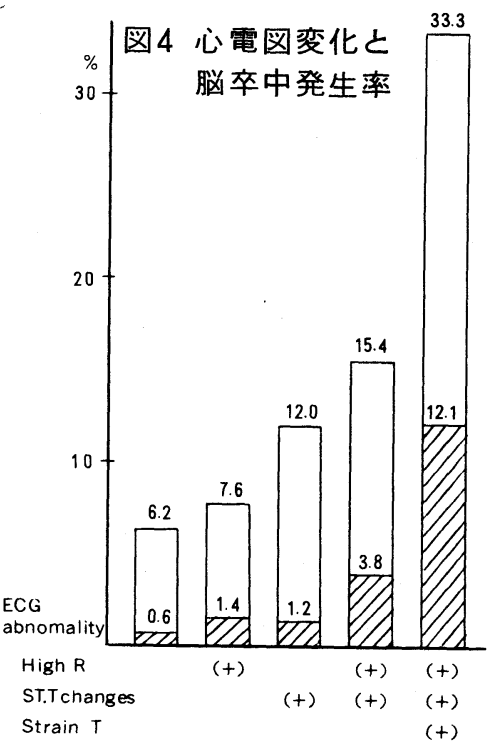

$\%$ 図5 眼底変化と
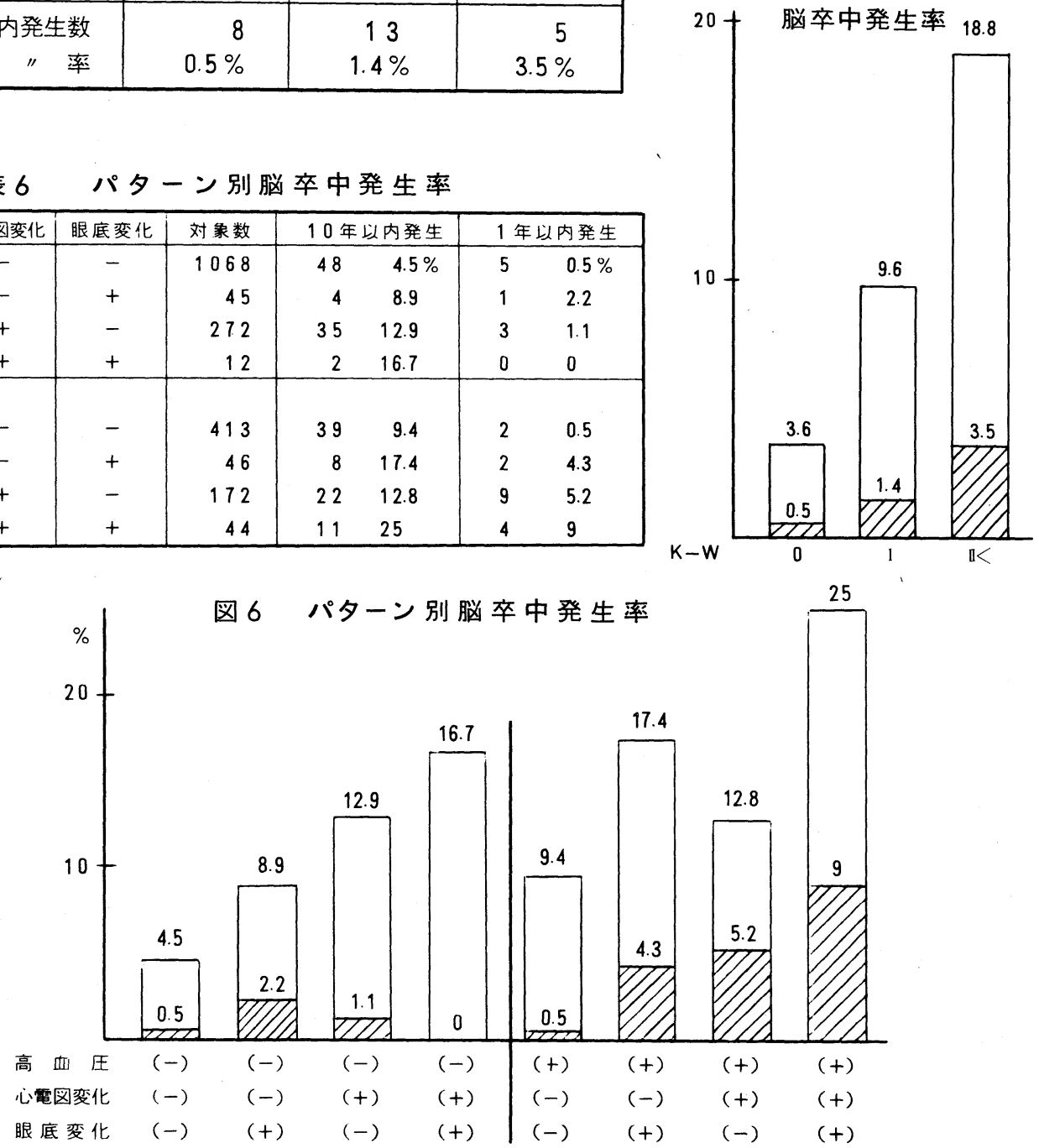
虚血性脳血管障害の近接予知

一不整脈を中心に一

細谷 賢一（秋田県厚生連 平鹿総合病院 第二内科）

〔はじめに〕

近年、食生活の改善により、脳卒中の発生率は、減少傾向にあるあのの人口の高齢化が著し い農村部においては、依然として高い発生率を示している。心房細動は、人口の高齢化ととも に増加傾向にあるが、左房内血栓の合併を招来しやすいことから、脳塞栓症の危険因子として きわめて重要と考えられる。今回、心房細動をとりあげ、虚血性脳血管障害の危険因子として の重要性について検討し、若干の知見を得たのでててに報告し、その対策について付言する。

\section{〔 I 〕心房細動432例からみた虚血性脳血管障害}

対 象 昭和57年 1 月から 61 年 2 月までの50力月間に観察された持続性心房細動 318 例、一 過性心房細動 114例、計432例を対象とした。男女比は $2 ： 1$ (男 286 例、女148例）で、年 齢は 22 歳 $８ 9$ 歳、平均 $65.1 \pm 11.2$ 歳（男 $64.2 \pm 11.2$ 歳、女 $66.1 \pm 11.3$ 歳）であった。

方 法 心房細動 432 例の年代別構成、基礎心疾患、主な合併疾患について検討した。次に 持続性心房細動75例の左房径の大きさ、ホルター心電図記録を施行した持続性心房細動45例の 総心拍数および心拍数の日内変動の大きさを計測した。また432例中、短時間記録心電図にて 徐脈傾向を呈した 97 例について延べ143回の Holter 心電図記録を施行し、最長 3 秒以上の Ventricular Pause を持っ群をLong Ventricular Pause Group（LVPG）、持たない 群をNon LVPG(NLVPG) とし以下の検討を行った。

(1) 左房径、総心拍数抢よび心拍数の日内変動の大きさが虚血性脳血管障害の発生率に及ぼす 影響について。

(2) LVPGとNLVPGに打ける虚血性脳血管障害（一過性脳虚血発作屯含む）の発生率の 差違について。

(3) LVPGとNLVPGに打ける心臓薬使用率の差異について。

(1)(2)(3)のととから、心房細動の左房径打 よび心拍数が虚血性脳血管障害の発生率に およぼす影響を㭘討し、その薬物使用法お よび対策について考察した。

結果および考察 心房細動 432 例の年代 別構成では、 50 代、60代、70代に多く、人 口構成を考慮すると高齢化とともに増加し て打り、各年代とあ男女比は扰よそ2：1 であった（図 1)。

基礎心疾患では弁膜症が 109 例（25.2\%）

図 1. 心房細動 432 例の年代別構成

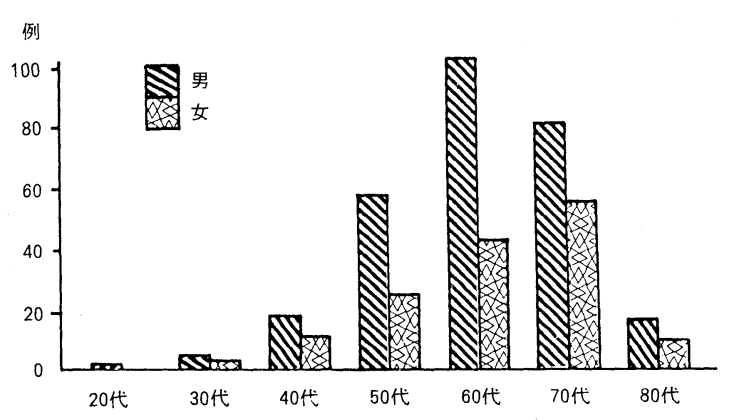
ともっとも多く、次いで冠動脈疾患の 91 例 (21.1\%) であった（図 2）。 
主な合併疾患では、高血圧症が 162 例 (37.5\%) でもっとも多く、次いで虚血性 脳血管障害が 100 例（23.2\%）、糖尿病、 高脂血症、慢性呼吸器疾患の順で、甲状腺 機能穴進症は比較的少なかった。虚血性脳 血管障害の合併率は、出血性脳血管障害の 2 例 $(0.46 \%)$ に·比し 100 例 $(23.2 \%)$ と きわめて高く、また、100例中、心房細動 以外飞高血圧症、糖尿病、高脂血症等の合 併症のないものが52例（52\%）と多いてと から、半数以上は心房細動に伴う左房内血 栓形成による塞栓が原因と考えられた。

(図 3 ) 。

次に、脳梗塞合併心房細動群と非合併心 房細動群の左房径を超音波 $\mathrm{M}$ モドにて計 測し比較したが両群間に差を認めなかった

（図4）。心拍数の比較では、1 日の総心 拍数は脳梗塞群で減少傾向を認めたが推計 学的に有意差を認めなかった（図 5 ）。ま た、1 時間毎の心拍数に差目し、その最大 值と最小值の差および隣接する 2 時間の心 拍数の差の最大值（Near $\triangle \mathrm{Max}$ ) を求め、 心拍数の変動の程度と脳梗塞発症との関連 性について検討したが、いづれに扔いても 両群間に有意差を認めなかった。

次に、LVPG抢よび NLVPGに打け る虚血性脳血管障害の合併率を比較すると N L V P G では $22.0 \%$ であるのに対し、LVPGでは 30.4\% と推計学的に有意ではな いものの高い傾向を示した。また、てれら 虚血性脳血管障害例中、心房細動以外の危 険因子（高血圧、糖尿病、高脂血症）を合 併していない例を比較すると、NLVPG の 49.4\%に対し LVPGでは $71.4 \%$ と高率 であった（図6）。乙れらのことは、Ventricular Pause の長い心房細動例におい て虚血性脳血管障害の合併率がより高いこ とを示唆しており、その原因としては、著 しい徐脈による左房内平均血流速度の低下 が左房内血栓形成を促進している可能性が
図 2.

心房細動 432 例基礎心疾患

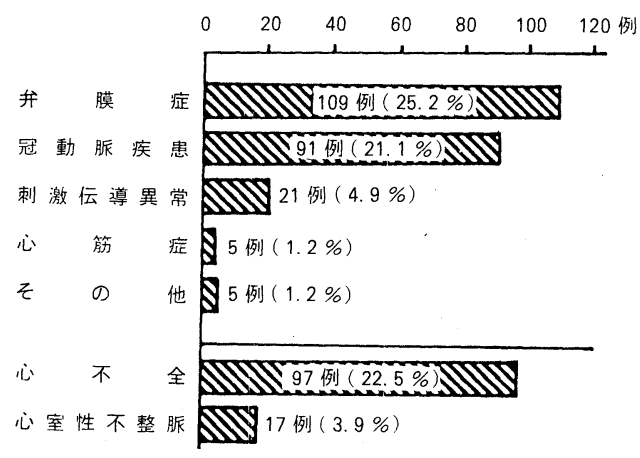

図 3.

心房細動 432 例の主な合併疾患

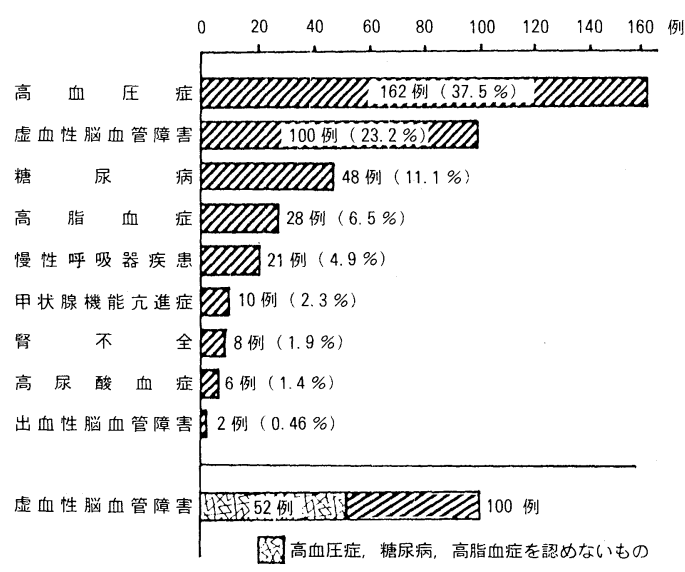

図 4. 脳硬塞合併心房細動群および脳梗塞 非合併心房細動群における左房经の比較

\begin{tabular}{|c|c|c|}
\hline & $\begin{array}{c}\text { 脳硬塞 合併群 } \\
\bar{x} \pm S D\end{array}$ & $\begin{array}{c}\text { 脳硬塞非合併群 } \\
\bar{x} \pm S D\end{array}$ \\
\hline $\begin{array}{c}\text { 左房 径 } \\
(\mathrm{cm})\end{array}$ & $\begin{array}{c}3.95 \pm 0.93 \\
(\mathrm{n}=48)\end{array}$ & $\begin{array}{c}3.66 \pm 0.74 \\
(\mathrm{n}=27)\end{array}$ \\
\hline
\end{tabular}

図 5. 脳硬塞合併心房細動群およひ脳硬塞 非合併心房細動群における心拍数の比較

\begin{tabular}{|c|c|c|}
\hline & $\begin{array}{c}\text { 脳硬塞合併群 } \\
\bar{x} \pm S D\end{array}$ & $\begin{array}{c}\text { 脳硬塞非合併群 } \\
\bar{x} \pm S D\end{array}$ \\
\hline $\begin{array}{l}\text { Total QRS } \\
\text { (beat day) }\end{array}$ & $\begin{array}{c}89476.9 \pm 19795.7 \\
(n=15)\end{array}$ & $\begin{array}{c}94897.4 \pm 18633.8 \\
(n=30)\end{array}$ \\
\hline $\begin{array}{l}\text { Max QRS } \\
\text { - Min QRS } \\
\text { (beat hour) }\end{array}$ & $\begin{array}{c}1366.2 \pm 471.1 \\
(n=15)\end{array}$ & $\begin{array}{c}.1507 .3 \pm 597.6 \\
(n=30)\end{array}$ \\
\hline $\begin{array}{l}\text { Near } \triangle M a x \\
\text { (beat } / \text { hour) }\end{array}$ & $\begin{array}{c}702.1 \pm 293.6 \\
(n=15)\end{array}$ & $\begin{array}{c}771.2 \pm 349.3 \\
(n=29)\end{array}$ \\
\hline $\begin{array}{l}\triangle \mathrm{Max} \\
\text { (beat } / \min )\end{array}$ & $\begin{array}{c}50.1 \pm 26.7 \\
(n=15)\end{array}$ & $\begin{array}{c}50.3 \pm 20.8 \\
(n=29)\end{array}$ \\
\hline
\end{tabular}


考えられる。

次に LVPG、NLVPGに抢ける心臓 薬の使用状況を比較すると、 digitalisの 使用率ではLVPG43.4\%、NLVPG39.1\%と ほぼ同率であるが、Ca-antagonist、

$\beta$-blocker扰よびこれら薬剤の併用では、

NLVPGに比しLVPGでは 2〜 4 倍と明らか に高率であった（図７）。心房細動におい てしばしば使用されるこれら薬剤の使用に 際しては、著しい徐脈の誘発と、それによ る左房内血栓形成促進の可能性を考慮し、 Adams-Stokes 発作のみならず脳塞栓症予 防上に打いても充分な注意が必要と考えら れる。

\section{〔II 〕虚血性脳血管障害182例からみた 心房細動}

対象 当科に入院した脳梗塞症で CT または血管造影により部位の確認出来た男 111 例、女 71 例で計 182 例を対象とした。 年齢は 41 歳〜87歳、平均 65.9 歳であった。 対象群として山内村老人検診受診者 140 例 （平均年齢68.9歳）を用いた。

方 法 脳梗塞症 182 例と対象群 140 例 の心電図所見を検討し、脳梗塞症例の年齢 別心房細動合併率を観察した。次に脳梗塞 症 182 例のCT所見を観察し、洞調律群と 心房細動群のCT所見の差異について検討 した。

結果および考察 脳梗塞症 182 例と対象 群140例の心電図所見では心房細動、左室 肥大、 $\mathrm{S}$ T低下、 $\mathrm{T}$ 波逆転が脳梗塞群で有 意に多かった。乙のうち、心房細動の合併 率は、対象群の $1.4 \%$ に対し脳梗塞群では $23.6 \%$ と著しく高く、推計学的に有意 $(P$ $<0.001$ ) であった（表 1 ）。脳梗塞症例 の年齢別心房細動合併率では高齢者程高い 傾向を示した（表2）。乙れらのととから、 心房細動は脳梗塞症の原因としてきわめて 重要な因子であり、その重要性は高齢者程
図 6.

LVPG, NLVPGにおける 虚血性脳血管障害合併率

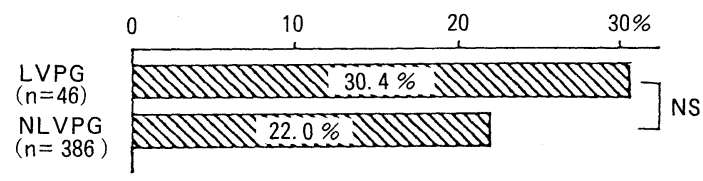

虚血性脳血管障害例中

心房細動以外の危険因子を認めないもの

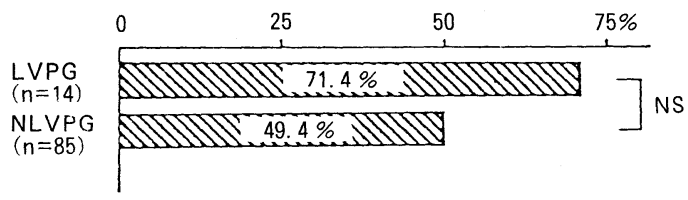

NS : not significant

図 7.

Comparison of Drugs between

Long Ventricular Pause Group (LVPG) and Non LVPG.

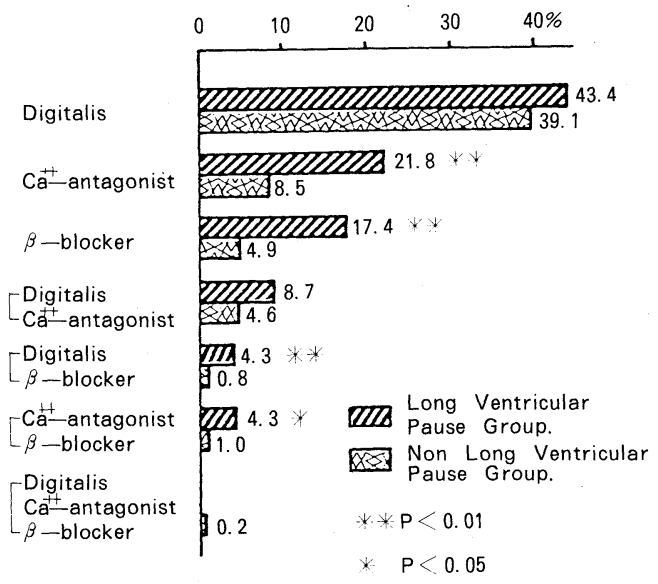

表 1. 脳硬塞症 182 人と

コントロール 140 人の心電図所見

\begin{tabular}{|c|c|c|}
\hline 心電図所見 & 脳硬塞症 & コントロール \\
\hline 正常範 团 & $30^{* * *}(16.5 \%)$ & $56(40.0 \%)$ \\
\hline O T 延長 & $4 \quad(2.2 \%)$ & 0 \\
\hline$T$ 波逆転 & $66^{* * *}(36.3 \%)$ & $18(12.9 \%)$ \\
\hline S T 低下 & $62^{* *}(34.1 \%)$ & $26(18.6 \%)$ \\
\hline 左室肥大 & $73^{* * *}(40.1 \%)$ & $26(18.6 \%)$ \\
\hline 異 常 O 波 & $13 \quad(7.1 \%)$ & $3(2.1 \%)$ \\
\hline 心房 細 動 & $43^{* * *}(23.6 \%)$ & $2(1.4 \%)$ \\
\hline 頻＼cjkstart㟲 & $9 \quad(4.9 \%)$ & 0 \\
\hline 脈 & $14 \quad(7.7 \%)$ & 0 \\
\hline
\end{tabular}


増す傾向にあるあのと考えられる。

次に、脳梗塞 182 例の C T 所見を洞調律 群139例と心房細動群 43 例に分けて比較し てみると、小梗塞では、洞調律群の $38.1 \%$ に対し心房細動群では $16.3 \%$ と推計学的に 有意 $(P<0.01)$ に低く中梗塞は両群とも 同程度、大梗塞では洞調律群の $6.5 \%$ 亿対 し心房細動群では39.5\% と有意 $(\mathrm{P}<0.001)$ に高かった（表 3 ）。また、出血性梗塞と なったものは、洞調律群の $3.6 \%$ に対し心 房細動群では $23.3 \%$ と有意に高かった

（表 3 ）。

脳梗塞 182 例中、急性期死亡例は 17 例 (9.3\%) あり、うち、10例は心房細動群で あり、心房細動群で有意 $(\mathrm{P}<0.001)$ に 急性期死亡例が多かった（表 4)。乙れら のことは、心房細動合併群の脳梗塞は大梗 塞となりやすく、急性期死亡率も高いこと を示している。

\section{結語}

（1）心房細動の合併は高齢者ほど多く、男 女比は各年代とあ执よそ2：1であった。

（2）心房細動患者の虚血性脳血管障害合併 率は $23.2 \%$ ありり、虚血性血管障害患者 の心房細動の合併率は23.6\%であった。

(3) 左房径の大きさおよび心拍数の日内変 動の大きさと虚血性脳血管障害の合併率 との間に相関を認めなかったが、徐脈傾 向の著しい心房細動例 (Ventricular-

Pause 3 秒以上）に虚血性脳血管障害の合 併率が高い傾向を認めた。

(4) 徐脈傾向の著しい心房細動例ではCaantagonist、 $\beta$ - blockerの使用率打よび その併用率が有意に高く、使用上注意を 要する。

(5) 心房細動合併群の脳梗塞は大梗塞が多 く、出血性梗塞となるすのが多かった。 また、急性期死亡率も高かった。

\section{表 2. 脳硬塞症例の年齢別心房細動合併率}

\begin{tabular}{l|c|c|c}
\hline \multicolumn{1}{l|}{ 年 } & 夦 & 心房細動症例数(男) 全症例数(男) & 合 併 率 \\
\hline $40 \sim 49$ & $0(0)$ & $8(5)$ & $0 \%$ \\
$50 \sim 59$ & $4(2)$ & $35(29)$ & $11.4 \%$ \\
$60 \sim 69$ & $18(12)$ & $69(43)$ & $26.1 \%$ \\
$70 \sim 79$ & $14(8)<58(26)$ & $24.1 \%$ \\
$80 \sim$ & $7(5)<12(8)$ & $58.3 \%$ \\
\hline
\end{tabular}

表 3. 脳硬塞症 182 人の C T 所見

\begin{tabular}{|c|c|c|c|}
\hline 硬塞巣の大きさ & 硬塞 部 位 & $\begin{array}{c}\text { 洞 調 律 } \\
\text { (出血例) }\end{array}$ & $\begin{array}{c}\text { 心房細 動 } \\
\text { (出血列) }\end{array}$ \\
\hline \multirow{2}{*}{ 小 } & 正 常 & 10 & 2 \\
\hline & ラクーネ & 43 & 5 \\
\hline 小 計 & & $\begin{array}{l}53 .(1) \\
(38.1 \%)\end{array}$ & $(16.3 \%)$ \\
\hline \multirow{7}{*}{ 中 } & MCA 穿通枝領域 & 41 & $7(1)$ \\
\hline & MCA 皮質枝領域 & $8(1)$ & $6(1)$ \\
\hline & $P \quad C \quad A$ & $9(1)$ & $4(1)$ \\
\hline & $A \quad C A$ & 0 & 1 \\
\hline & 小脳 & $9(1)$ & 0 \\
\hline & 橋 & 9 & 1 \\
\hline & 脳 & 1 & 0 \\
\hline 小 計 & & $\begin{array}{l}77 .(3) \\
(55.4 \%) \\
\end{array}$ & $\begin{array}{l}19.3) \\
(44.2 \%)\end{array}$ \\
\hline \multirow{3}{*}{ 大 } & MCA 皮質枝一穿通枝 & $8(1)$ & $12(7)$ \\
\hline & $M C A+P C A$ & 0 & 2 \\
\hline & 脳底動脈 & 1 & 3 \\
\hline 小 計 & & $(8.5 \%)$ & $\begin{array}{l}17+5 \%(7) \\
(39.5 \%)\end{array}$ \\
\hline 計 & & $139(5)$ & $43(10) \div \cdots$ \\
\hline
\end{tabular}

表 4. 急性期死亡例のC T 所見

\begin{tabular}{|c|c|c|c|}
\hline 硬塞果の大きさ & 硬 塞 部 位 & 全脳硬塞症 & 心房細動 \\
\hline \multirow{2}{*}{ 小 } & 正常 & 3 & 1 \\
\hline & ラクーネ & 1 & 0 \\
\hline 計 & & 4 & 1 \\
\hline \multirow{7}{*}{ 中 } & MCA穿通枝領域 & 0 & 0 \\
\hline & MC A 皮質枝領域 & 0 & 0 \\
\hline & $\mathrm{P} \quad \mathrm{C} \quad \mathrm{A}$ & 0 & 0 \\
\hline & A $\quad$ C $A$ & 0 & 0 \\
\hline & 小 脳 & 0 & 0 \\
\hline & 橋 & 1 & 0 \\
\hline & 中 脳 & 0 & 0 \\
\hline 計 & & 1 & 0 \\
\hline \multirow{3}{*}{ 大 } & MCA皮質枝＋穿通枝 & 7 & 6 \\
\hline & $M C A+P C A$ & 1 & 0 \\
\hline & 脳 底 動 脈 & 4 & 3 \\
\hline 計 & & 12 & 9 \\
\hline 計 & & $\begin{array}{l}17 / 182 \\
(9.3 \%)\end{array}$ & $\begin{array}{c}10 * * * * 43 \\
(23.3 \%)\end{array}$ \\
\hline
\end{tabular}


虚血性脳血管障害の近接予知

\section{一心疾患を中心に}

\section{藤 原 秀 臣}

(土浦協同病院内科)

腷卒中発症の近接予知は疫学および臨木上極めて興味深く重要な課題で ある。脳卒中の発症はそのひきがねとなる内的および外的因子と基盤飞あ る脳血管病変との関連のうえに成り立つており，多角的なアプローチが必 要である。一般に心疾患と直接関連するとされているものには心内血栓形 成との関係で弁膜症，心房細動，ペースメーカ一患者などがあるとされて らるが必ずしも明確な関連性は証明されていない。そこで脳卒中および心 筋梗塞飞おける危険因子の関与, 脂質の遺云学的解析, ペースメーカ一患 者と脳卒中の関連性などについての検討を試みた。

\section{1.経過を把握しえた脳梗塞症例の検討}

1985 年 4 月加ら 1986 年 6 月の間飞発症した脳梗塞症例で，以前に一回以 上外来を受診したととのある患者 21 例を対象とした（表 1 ）。そのうち心疾 患は 7 例で, 内訳は心筋症 2 例 (肥大型心筋症 1 例, 拡張型心筋症 1 例), 弁膜症 2 例（僧帽弁狭窄症 1 例, 僧帽弁逆流症 1 例), ペースメ一カ一植込 み 2 例（ＶＶＩ２例），陳旧性心筋梗塞１例である。７例のうちで心房細動 は拡張型心筋症の 1 例と僧帽弁狭窄症の 1 例飞認められた。心エコ一図飞 よる心内血栓は僧帽弁狭窄症の 1 例飞認められた。また21例中で高血圧症 は 12 例（57.1\%） と半数以上飞 譛められ, 糖尿病は9例 (42.8\%) と半数近く飞認められた。以上 のことょり心疾患を合併した脳 梗塞においても心内血栓や心房 細動は比較的少いととが示唆さ れた。

$$
\text { 2.ペースメーカー植込み症 }
$$
例と脳卒中

$$
\text { ペースメーカー患者ではV V }
$$

エモードにおける心房一心室非 協動性のための房室弁逆流飞よ る心房内血栓や, 洞不全症候群 の一過性心房細動などにより腷 梗塞を合併しやすいとされてい る。そこで1973 年 4 月から1986 年 6 月までに当科において施行

\begin{tabular}{|c|c|}
\hline 総 数 & 21 例 $(1985.4 \sim 1986.6)$ \\
\hline 心疾患 & 7 例 \\
\hline 心筋症 & 2 例 \\
\hline 弁膜症 & 2 例 \\
\hline ペースメーカー & 2 例 \\
\hline 心筋梗塞 & 1 例 \\
\hline 心房細動 & 2 例 \\
\hline 心内血栓 & 1 例 \\
\hline 高血压症 & 1.2例 \\
\hline 糖尿病 & 9 例 \\
\hline 高血圧，糖尿病 & 1. 4 例 \\
\hline 高血圧＋糖尿病 & 7 例 \\
\hline
\end{tabular}

表 1. 経過を把握しえた脳梗塞症例 
したぺースメーカ一植込み患者 のうちでアンケート調查を含め 経過を観察しえた122例につい て脳卒中の発症例を検討した。 まず現在までの死亡例は32例 (26.2\%) と高率であるが，乙 れはペースメーカ一植込み患者 が高令であるととと観察期間が 最長13年と長期飞わたつている ことが関与していると考えられ る（表 2 ）。死亡の原因となつ た疾患は, 脳卒中 6 例, 悪性腫 瘍 4 例，心不全 7 例，老衰 2 例， 突然死 1 例，その他 2 例であつ た。一方ぺースメ一カ一植込及 症例飞おいては脳卒中の発症怔 7 例 (5.7\%)飞確認された（表 3 )。 年令は71〜83歳（平均 76.6 歳） で男性 4 例, 女性 3 例である。 そのうち 1 例のみ文生存してい るが他の6例は死亡している。 病型は腷梗塞 4 例, 脳出血 3 例 である。ペースメ一カ一適応と なつた基礎心疾患岋洞不全症候 群 3 例, 完全房室ブロック 4 例 で, ペーシングモード は全例 $\mathrm{V} V I$ （心室抑 制型デマンドペースメ 一カ一)である。との 結果からは脳卒中とぺ 一スメーカ一との関連 は明らかではなく，加 令水よる腷卒中発症驾 多いと思われるが, 生 存の 1 症例の みは発症,
表2.ペースメーカー植込み症例における死亡例

\begin{tabular}{|c|c|c|}
\hline 総 数 & & 122 例 $(1973.4 \sim 1986.6)$ \\
\hline \multirow[t]{7}{*}{ 死亡例 } & & 32 例 $(26.2 \%)$ \\
\hline & 脑卒中 & 6例 \\
\hline & 悪性腫瘍 & 4 例 \\
\hline & 心不全 & 7 例 \\
\hline & 老衰 & 2 例 \\
\hline & 突然死 & 1 例 \\
\hline & その他 & 2 例 \\
\hline
\end{tabular}

表3.ペースメーカー植込み症例における脳卒中の頻度

\begin{tabular}{|c|c|c|c|}
\hline 総 & 数 & \multicolumn{2}{|c|}{122 例 ( $1973.4 \sim 1986.6)$} \\
\hline \multicolumn{2}{|c|}{ 脳卒中 } & \multicolumn{2}{|l|}{7 例 } \\
\hline & 年令 & \multicolumn{2}{|c|}{ : $71 \sim 83$ 歳 ( 76.6 歳) } \\
\hline \multirow{2}{*}{\multicolumn{2}{|c|}{ 予後 }} & : 死亡 & 6例 \\
\hline & & 生存 & 1 例 \\
\hline & \multirow[t]{2}{*}{ 病型 } & :脳梗塞 & 4 例 \\
\hline & & 脳出血 & 3 例 \\
\hline & \multirow[t]{2}{*}{ 基礎心疾患 } & : 洞不全症候群 & 3 例 \\
\hline & & 完全房室ブロック & 4 例 \\
\hline & ペーシングモード & : V V I & 7 例 \\
\hline
\end{tabular}

表 4. 合併症の頻度

経過ともに畄梗塞と考えられ，ペースメーカーとの関連性が強く示唆され た。またぺーシングモードでは全例がVVIであるてとが注目されるが， A A I D D D な゙の生理的ぺーシングの植込及症例では術後の観察期間 が短加にとる考慮する必要があると考兄られる。 
3.心筋梗塞と脳梗塞における危険因子

心筋梗塞も脳梗塞も動脈硬化（虚血性血管障害）を基盤として発症して くると考えられる。しかしその背景因子は必ずしす同一に論じるととは困 難である。そと で心筋梗塞と脳 表 5. 血清脂質の平均值 $(\mathrm{mg} / \mathrm{d} \mathrm{l})$

梗塞患者につい て，動脈硬化の 危険因子として 代表的な高血压 症，糖尿病，高 脂血症の関与の 仕方儿差異があ

\begin{tabular}{llcc}
\hline \hline & $\begin{array}{c}\text { 心筋梗塞 } \\
(\mathrm{n}=74)\end{array}$ & $\begin{array}{c}\text { 脳梗塞 } \\
(\mathrm{n}=21)\end{array}$ & $\begin{array}{c}\text { ドッn受診者 } \\
(\mathrm{n}=112)\end{array}$ \\
\hline 総コレステロール & $207 \pm 52^{*}$ & $174 \pm 64$ & $191 \pm 40$ \\
トリグリセライド & $174 \pm 95^{* *}$ & $119 \pm 78$ & $124 \pm 71$ \\
\hline \hline
\end{tabular}
る加を検討した。

対象は心筋梗塞77例と脳梗 塞21例および対照としてのド 表 6. 心筋梗塞症例と健常者におけるアポE 表現型 ツク受診者 110 例である（表 4 )。その結果，高血圧症は 心筋梗塞で 37 例 ( $48.1 \%$ ) ,

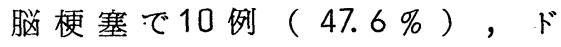
ック受診者で 28 例（ $25.4 \%)$ 飞みられ, 心筋梗塞, 脳梗塞 ともに有意飞高率であつた。 糖疗病は心筋梗塞で19例（24. 7\%), 脳梗塞で 4 例( $19.0 \%)$, ドック受診者で 8 例( $7.3 \%)$ 飞みられ，やはり心筋梗塞, 䑈梗塞と为飞対照飞比し高率 であつた。一方, 高脂血症は

\begin{tabular}{|c|c|c|}
\hline $\begin{array}{l}\text { アポE } \\
\text { 表現型 }\end{array}$ & $\frac{\text { 心筋梗塞 }}{\mathrm{n}(\%)}$ & $\frac{\text { 健常者 }}{\mathrm{n}(\%)}$ \\
\hline $3 / 3$ & $67(69.8)$ & $179(68.1)$ \\
\hline $3 / 4$ & $16(16.7)$ & $5.0(19.0)$ \\
\hline $2 / 3$ & $7(7.2)$ & $18(6.8)$ \\
\hline $2 / 4$ & $2(2.1)$ & $5(1.9)$ \\
\hline $4 / 4$ & 0 & $4(1.5)$ \\
\hline $2 / 2$ & 0 & $1(0.4)$ \\
\hline $3 / 7$ & $\left.{ }^{1}\right\} 2(2.1)$ & $3\} 3(1.1)$ \\
\hline $4 / 7$ & $1\}<(2.1)$ & 0 ( \\
\hline $3 / 5$ & $1\} 2(2.1)$ & $2\} 3(1.1)$ \\
\hline $2 / 5$ & $1)(2 \mathrm{x})$ & 150 \\
\hline & $96(100)$ & $263(100)$ \\
\hline
\end{tabular}
心筋梗塞で39例（ $50.7 \%$ ）， 脳梗塞で 3 例（14.2\%），ドック受診者で 29 例（26.3\%）と脳梗塞では低率であつた。 表 7. 脳梗塞症例とアポE 表現型 ちなみ飞血中脂質の平均値をみてみると， 心筋梗塞では総コレステロール207土5 $2 \mathrm{mg}$ $/ \mathrm{dl}$, トリグリセライド $174 \pm 75 \mathrm{mg} / \mathrm{dl}$ と いずれる対照例飞比し有意飞高値であつた が，兽梗塞では総コレステロール，トリグ リ七ライドともに有意差はなかつた（表5）。 この結果は脳梗塞症例が少く, 他の因子の 関与る大きいので明確なととは言及でをな

\begin{tabular}{rr}
\hline アポ $\mathrm{E}$ & $\begin{array}{c}\text { 脳梗塞症例 } \\
\mathrm{n}\end{array}(\%)$ \\
\hline $3 / 3$ & $14(77.7)$ \\
$3 / 4$ & $3(16.6)$ \\
$2 / 3$ & $1(5.7)$ \\
\hline & $18(100)$ \\
\hline
\end{tabular}


らが, 脳梗塞に高脂血症の関与が少い傾向は興味深く，今後の検討が必要 である。

\section{4.アポE 遺伝子型の検討}

リポタンパクのタンパク質であるアポタンパクは脂質の代謝と樑いかか わりを持つととが判明してをている。アポタンパクのなかでもアポ上は遺 云的変異型の頻度が高く，特に日本人では欧米人には殆んどみられないと されているアポE 5 型，7型が心筋梗塞や高脂血症患者の約 $5 \%$ 亿検出さ れ動脈硬化の危険因子のひとつとして注目されている。そこで最初に心筋 梗塞におけるアポE遺质子型についての検討を試みた。対象は心筋梗塞96 例で，ドック受診者は263 例を対照とした（表6）。その結果，心筋梗塞 ておいてはアポE表型3/3は67例（69.8\%）飞，3/4は16例（16.7\%）

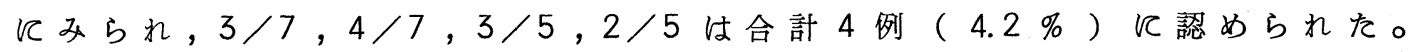
一方健常者では3/3は 179 例 (68.1\%) 飞，3/4は50例（19.0\%）飞認め られ，3/7，3/5，2/5は合計 6 例（2.2\%）飞認められた。すなわち， アポ $\mathrm{E} 5,7$ 型は心筋梗塞に多い傾向が示唆された。

さらに脱梗塞症例飞おけるアポE表現型の検討を試みた（表7）。対象 が未だ18例と少く，比較検討するととは困難であるが，アポ区表現型は， $3 / 3$ が14 例 ( $77.7 \%) ， 3 / 4$ が 3 例 ( $16.6 \%) ， 2 / 3$ が 1 例（ $5.7 \%)$ て あり，5，7型は検出されていない。今後症例を追加して心筋梗塞との間 における出現頻度の差異を検討する予定である。

\section{5 . 総 括}

脳卒中発症の近接予知について心疾患の見地加ら検討を加えた。心疾患 自体が脳卒中のひきが壮てなるととは少いと考えられるが，心内血栓や脳 偱環と関連した心血行動態は無関係ではないと考えられる。また，動脈硬 化を基盤として発症する心筋梗塞と腷梗塞との関連性の有無は興味媣い課 題である。今回の検討は自施設だけの少数例であり，多くを論じるととは できないが，心房細動や心内血栓との関連が必ずしも明らかでないものも 多いとと, ペースメーカーに関連した畄梗塞も必ずしも多くはないととな ぞが注目された。一方, 危険因子の検討では, 高血压症, 糖尿病の関与は 心筋梗塞, 腷梗塞ともに高いが, 高脂血症については様相が異る可能性が 示唆された。脂質代謝に関連したアポ $\mathrm{E}$ 遺质子型の検討では，心筋梗塞に おいてアポ $\mathrm{E} 5 ， 7$ 型が $4.2 \%$ 検出されている。腷梗塞については明確な ことは言及でをないが，少くとも現時点でのアポ $\mathrm{E} 5,7$ 型は検出されて いない。今後この手法により遺卮的素因の明らかな家系が検出された場合， 家系調查などから畄梗塞と心筋梗塞の発症素因における関連性を探るとと ができるのみならず, 家系内未発症の若年者における腷卒中の発症予知予 防子可能であると考えられる。 


\section{追加発言}

心機図による脳卒中近接予知について

神奈川歯科大学 内科関博人

脳卒中の発症は笑発的ではあるが，発病に至るまでに，高血圧，脳動脈硬化症などの， 基礎疾患が悪化して発病した過程が存在する。その悪化の過程の，いずれかの点で将来の 発作を予知できるような，徵候を捕らえることが可能ならば，農村における脳卒中発病阻 止に役立つとかんがえるＨｏllanderによれば脳卒中発病過程において，脳卒中 発病の促進因子として, 心不全, 不整脈, 脳動脈硬化の促進因子として脂質代謝異常, 糖 尿病などが指摘さるる。そこでそのようなことが実際に起こっているかを農村高血圧集団 や，糖尿病集団について検討した

農村高血圧ならびに糖尿病集団で実際に心機能低下があるかを心機図のS T I （収縮期時 相）を用いて分析したのが表 1 , 表 2 , 表 3である。 E T く P E P は心指出量, P d / I $\mathrm{C}$ Tは心収縮力の指標であり， R T (趾端脈波伝達時間) は動脈硬化度と逆比例し, P m ／RTは末梢抵抗の指標である．高血圧も糖尿病も重症化するにつれ，心機能の低下，末 梢抵抗の增大がみられる。

表 1 正常者の心機図所見（女,30 歳以上）

\begin{tabular}{|c|c|c|c|c|c|c|c|c|}
\hline \multirow{3}{*}{$\mathbf{N}$} & \multirow{2}{*}{\multicolumn{2}{|c|}{$\frac{I: 30 \text { 歲代 }}{28}$}} & \multirow{2}{*}{\multicolumn{2}{|c|}{$\frac{\text { II :40・50歳代 }}{48}$}} & \multirow{2}{*}{\multicolumn{2}{|c|}{$\frac{\text { III:60 歳以上 }}{10}$}} & \multirow{3}{*}{\multicolumn{2}{|c|}{$t$-test }} \\
\hline & & & & & & & & \\
\hline & $\bar{x}$ & SD & $\overline{\mathrm{x}}$ & $\mathrm{SD}$ & $\bar{x}$ & $\mathrm{SD}$ & & \\
\hline$/ \mathrm{PE}$ & 4.53 & 1.451 & 3.89 & 1.358 & 3.38 & 1.432 & I : II * & \\
\hline$d / I C T$ & $265 ?$ & 2065 & 1650 & 981 & 1385 & 796 & I : II & III \\
\hline RT & 0.28 & 0.031 & 0.27 & 0.028 & 0.26 & 0.020 & I : III* & \\
\hline $\mathrm{Pm} / \mathrm{RT}$ & 300 & 52 & 325 & 50 & 349 & 39 & I : Il * & I : III* \\
\hline
\end{tabular}

表 2 農村高血厌者の心機四所見

(1). (女40 65歳)

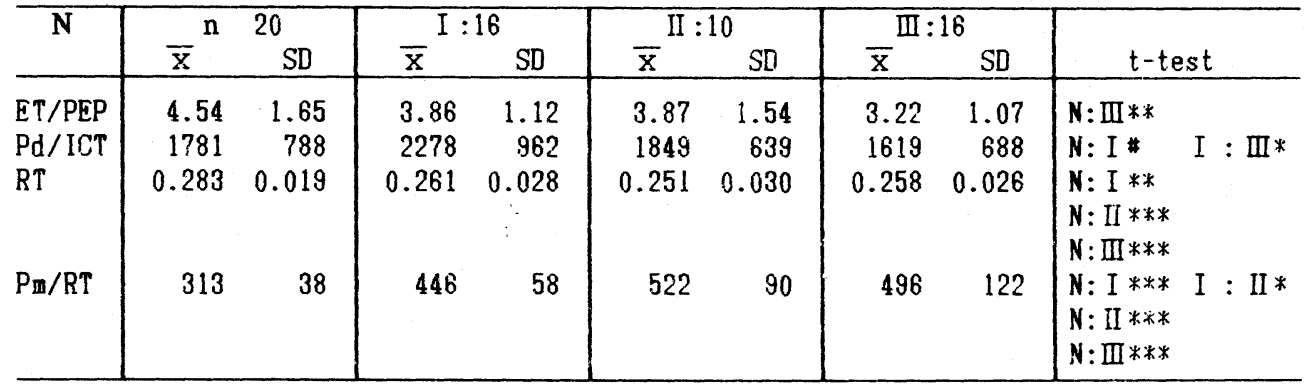

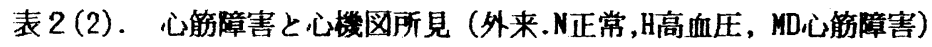

\begin{tabular}{|c|c|c|c|c|c|c|c|c|}
\hline & \multirow{2}{*}{\multicolumn{2}{|c|}{$\frac{N: \operatorname{MD}(-)}{\frac{19}{49.5}(41 \sim 58)}$}} & \multicolumn{2}{|c|}{$I: H \quad M D(+)$} & \multicolumn{2}{|c|}{ II :H MD(+) } & \multirow{2}{*}{\multicolumn{2}{|c|}{ t-test }} \\
\hline $\begin{array}{r}\mathbf{N} \\
\text { AGE }\end{array}$ & & & $\frac{50.0}{x}$ & $\begin{array}{c} \\
\quad \sim 62) \\
S D\end{array}$ & $\frac{49.1}{x}$ & $\begin{array}{l}4 \\
2 \sim 57) \\
\text { SD }\end{array}$ & & \\
\hline ET/PEP & 3.546 & 1.186 & 3.145 & 0.731 & 2.65 & 0.553 & $N:$ II ** & I $: \mathbb{I I} \#$ \\
\hline $\mathrm{Pd} / \mathrm{ICT}$ & 1650 & 1070 & 1612 & 483 & 1399 & 432 & & \\
\hline $\mathrm{RT}$ & 0.26 & 0.02 & 0.25 & 0.01 & 0.26 & 0.03 & & \\
\hline $\mathrm{Pm} / \mathrm{RT}$ & 338 & 137 & 441 & 28 & 441 & 88 & $N: I *$ & $\mathrm{~N}:$ II $* *$ \\
\hline
\end{tabular}


表 3 榶尿病の重症度と心機図所見

\begin{tabular}{|c|c|c|c|c|c|c|c|c|c|c|}
\hline \multirow[t]{2}{*}{$\mathbf{N}$} & \multicolumn{2}{|c|}{$\begin{array}{l}\text { n } 20 \\
20\end{array}$} & \multicolumn{2}{|c|}{$\begin{array}{c}I: 16 \\
12\end{array}$} & \multicolumn{2}{|c|}{$\begin{array}{c}\text { II }: 10 \\
14\end{array}$} & \multicolumn{2}{|c|}{$\begin{array}{c}\text { III }: 16 \\
10\end{array}$} & \multirow{2}{*}{\multicolumn{2}{|c|}{ t-test }} \\
\hline & $\bar{x}$ & SD & $\bar{x}$ & SD & $\bar{x}$ & SD & $\bar{x}$ & SD & & \\
\hline $\mathrm{ET} / \mathrm{PEP}$ & 3.95 & 1.08 & 3.01 & 0.56 & 2.33 & 0.87 & 2.02 & 0.98 & $\begin{array}{l}N: I * * \\
N: \text { II ** } \\
N: \text { III** }\end{array}$ & $\begin{array}{l}I: I I * \\
I: I I * *\end{array}$ \\
\hline $\mathrm{Pd} / \mathrm{ICT}$ & 1418 & 345 & 1176 & 130 & 882 & 292 & 1065 & 190 & $\begin{array}{l}N: \text { II *** } \\
N: \text { III** }\end{array}$ & $\begin{array}{l}I: \text { II \# } \\
\text { I : III\# }\end{array}$ \\
\hline $\mathrm{RT}$ & 0.273 & 0.026 & 0.249 & 0.023 & 0.250 & 0.021 & 0.241 & 0.023 & $\begin{array}{l}N: I * \\
N: I I * \\
N: I I I *\end{array}$ & \\
\hline $\mathrm{Pm} / \mathrm{RT}$ & 331 & 46 & 408 & 76 & 420 & 72 & 489 & 103 & $\begin{array}{l}N: I * * \\
N: \text { II ** } \\
N: \text { III** }\end{array}$ & II : III\# \\
\hline
\end{tabular}

$\# t s>p(0.10), * t s>p(0.05), * * t s>p(0.01), * * * t s>p(0.001)$

凶 1 は 6 例（男 5 例, 女 1 例）の脳卒中（梗塞 5 例, 出血 1 例）平均年齢 72.0 歳（ $\mathrm{S} \mathrm{D}=4.5 ）$ 患者の発作前の心機図の経過を 1 年間にわたつて追跡したものである.用 いた指標をあげると，心拍出量はインピーダンスカルヂオグラムから算出した k v（m 1 ), $\mathrm{et} / \mathrm{ict}$, 心収縮力は $\mathrm{f}$ i $(\mathrm{mmhg} / \mathrm{sec} \times 10000)$, i c t ( m s e

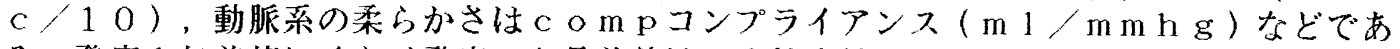
る。発病 1 年前值にくらべ発病一ケ月前值は, 心拍出量, 心収縮力の低下, コンプライア ンスの增大がみられ, 脳卒中発将前には, 後負荷の増加による心機能低下似よる心不全の 発生傾向があることが推測できた。また各種指標のなかで，一番最初に変化したのは，C om p コンプライアンスであつたが, compコンプライアンスの增大は後負荷の增加を 意味するので, 後負荷增加が心機能低下の原因であることがわかるとともに、脳卒中の予 知には c o m p コンプライアンスの変動を追うことが重要であるとかんがえられた.

図 1 脳卒中経過におけるS T I の変動

1 年前值と直前值比較

** $\mathrm{p}>0.01$

$* \mathrm{p}>0.05$
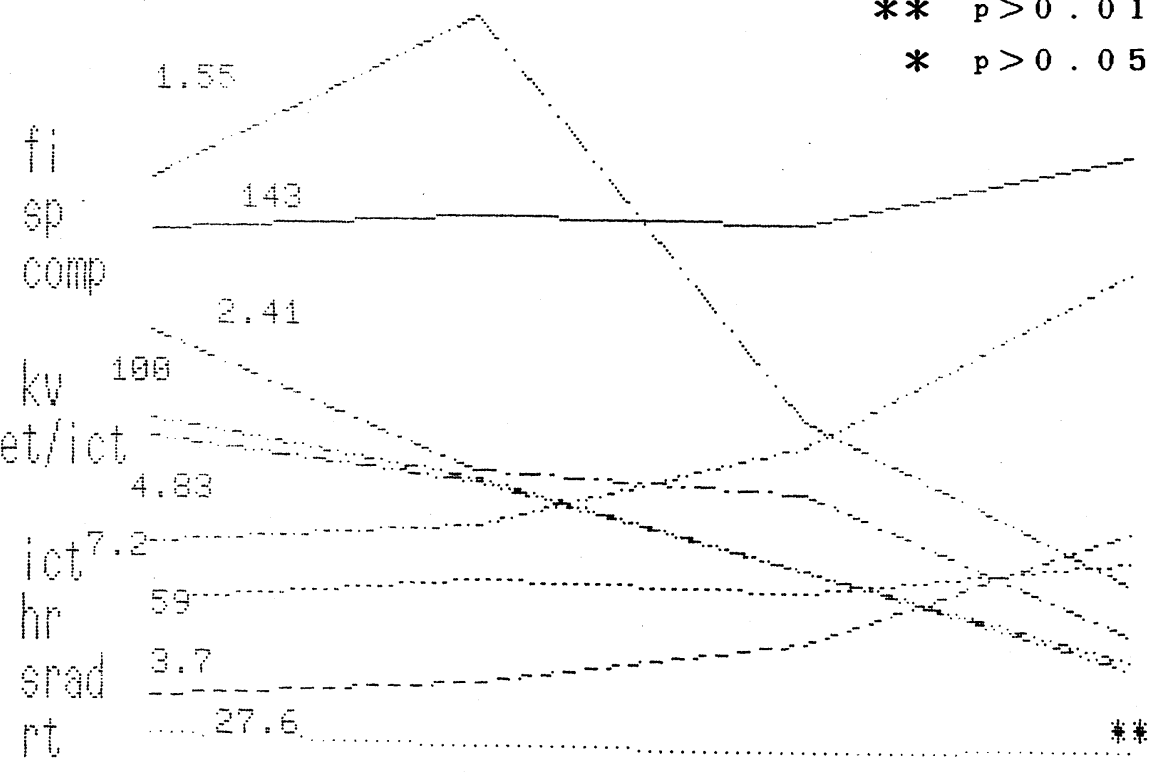

1E日. E w

19.4 絭索

$7.5 *$

ES

G.63*

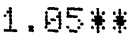

$46: 2.22 \%$

26.4 